IZA DP No. 10051

Much Ado About Nothing? The Wage Effect of Holding a Ph.D. Degree But Not a Ph.D. Job Position

Giuseppe Lucio Gaeta Giuseppe Lubrano Lavadera Francesco Pastore

July 2016 


\title{
Much Ado About Nothing? The Wage Effect of Holding a Ph.D. Degree But Not a Ph.D. Job Position
}

Giuseppe Lucio Gaeta

University of Naples L'Orientale

and C.METO5

\section{Giuseppe Lubrano Lavadera}

University of Salerno

Francesco Pastore

Seconda Università di Napoli

and IZA

Discussion Paper No. 10051
July 2016

IZA

P.O. Box 7240

53072 Bonn

Germany

Phone: +49-228-3894-0

Fax: +49-228-3894-180

E-mail: iza@iza.org

\begin{abstract}
Any opinions expressed here are those of the author(s) and not those of IZA. Research published in this series may include views on policy, but the institute itself takes no institutional policy positions. The IZA research network is committed to the IZA Guiding Principles of Research Integrity.

The Institute for the Study of Labor (IZA) in Bonn is a local and virtual international research center and a place of communication between science, politics and business. IZA is an independent nonprofit organization supported by Deutsche Post Foundation. The center is associated with the University of Bonn and offers a stimulating research environment through its international network, workshops and conferences, data service, project support, research visits and doctoral program. IZA engages in (i) original and internationally competitive research in all fields of labor economics, (ii) development of policy concepts, and (iii) dissemination of research results and concepts to the interested public.
\end{abstract}

IZA Discussion Papers often represent preliminary work and are circulated to encourage discussion. Citation of such a paper should account for its provisional character. A revised version may be available directly from the author. 


\section{ABSTRACT}

\section{Much Ado About Nothing? The Wage Effect of Holding a Ph.D. Degree But Not a Ph.D. Job Position*}

This paper contributes to the literature on overeducation by empirically investigating its effects on wages among Ph.D. holders. We analyze data collected in 2009 by the Italian National Institute of Statistics (ISTAT) through a large cross-sectional survey of Ph.D. recipients that allowed us observing their work placement few years after the completion of their studies. We extend previous contributions by providing an analysis based on the identification of genuine overeducation as resulting from the interaction of respondents' assessments that concern the usefulness of their Ph.D. title in order to get and to carry out their current job. The potential endogeneity of self-reported genuine overeducation is corrected by using an instrumental variables approach where the provincial incidence of overeducation among those that share the same educational profile of respondents is used as instrument. Our results suggest that genuine over-education is particularly detrimental for individual wages. It leads to a wage penalty of about between $23 \%$ and $25 \%$, more than twice bigger than average, a sizeable gap for the country's compressed wage structure. These results allow us to better understanding the effects of job-education mismatch and provide some useful insights into the evaluation of the career outcomes of doctoral graduates.

JEL Classification: C26, I23, I26, J13, J24, J28

Keywords: job-education mismatch, genuine overeducation, overskilling, job satisfaction, wages, Ph.D. holders

Corresponding author:

Francesco Pastore

Department of Law

Seconda Università di Napoli

Palazzo Melzi, Piazza Matteotti

I-81055, Santa Maria Capua Vetere (Caserta)

Italy

E-mail: francesco.pastore@unina2.it

\footnotetext{
* Paper accepted for presentation at the XXXI Aiel Conference (Trento, 2016). We thank for useful comments all seminar participants. However, the responsibility of errors is only on the authors.
} 


\section{Introduction}

The economics literature classifies education as a merit good (Musgrave, 1956 and 1959) and highlights that a number of positive outcomes derive from it (Sianesi and Reenen, 2003; Harmon et al, 2003; Psacharopoulos, 1994 e 2004; Blundell et al., 1999). On the one hand, education provides private returns, i.e. higher wages for more educated people; on the other hand, it determines significant social externalities by inducing socially virtuous lifestyle (e.g. healthconscious behaviours, anti-crime attitudes) and by promoting innovation and knowledge diffusion which, in turn, stimulate productivity.

Starting from the seminal contributions by Freeman (1976) and Duncan and Hoffman (1981), a number of scholars investigated how individual private returns from education are affected by education-job mismatch and, more specifically, by overeducation, i.e. holding an individual level of education in excess of that which is required for the job carried out.

This paper aims to contribute to this literature by empirically investigating the effect of overeducation on Ph.D. holders' wages. We analyze data collected in 2009 by the Italian National Institute of Statistics (ISTAT) through a large cross-sectional survey of Ph.D. recipients in all fields of scientific research, who were interviewed a few (3 and 5) years after the completion of their doctoral studies.

Focusing on Italy has to be considered particularly appropriate for our study. Indeed, the annual number of new Ph.D. holders has dramatically increased in Italy from 2002 until 2012 (+300\%) and this increase happens to be higher than the one reported by other OECD countries (Auriol, 2010). During the same period, the number of R\&D personnel in Public Administration has remained substantially stable while it has risen slightly in Universities even if only over some specific years. Although R\&D personnel has grown in private enterprises in 2012 it still is lower than the $\mathrm{EU}(28)$ average. In this framework, previous research found that a few years after completing their doctoral studies, more than $50 \%$ of doctoral graduates define themselves as overeducated (Gaeta, 2015; Gaeta and Lubrano Lavadera, 2016).

Considering the time that university students take in Italy to get a tertiary degree (7-8 years on average), the effort they have to make to enter a Ph.D. program and be awarded this degree, the question arises whether they are actually getting a sufficient reward for the effort made.

Being focused on Ph.D. holders, this paper extends previous contributions that investigated the effects of overeducation on wages among university graduates (for recent surveys of this literature, see, among others, Leuven and Oosterbeek, 2011; Caroleo and Pastore, 2016). Furthermore, it also extends the previous literature focused on the causal effect of overeducation on wages among doctoral recipients (Bender and Heywood, 2009; Gaeta and Lubrano Lavadera, 2016) by providing a more detailed specification of the overeducation status that is based on the interaction of respondents' self-assessment of:

i) their overeducation defined as the uselessness of their Ph.D. title in order to get their current job;

ii) their overskilling, defined as the uselessness of skills acquired during doctoral studies in carrying out their job; 
iii) their satisfaction for the use of doctoral skills in their job.

Following Chevalier (2003), Mavromaras et al. (2013) and Pecoraro (2014), the interaction among these variables allows us isolating genuine overeducation, that is the combination of overeducation and overskilling or, alternatively the simultaneous presence of overeducation and satisfaction for the use of doctoral skills. At the same time, this also allows us identifying genuine matching that arises when the Ph.D. education is considered useful for getting the current job and there is also a positive evaluation of doctoral skills use or satisfaction for this specific aspect.

The potential endogeneity of self-reported over-education is corrected by implementing an instrumental variables approach where the provincial incidence of over-education among those that share the same educational profile of respondents is used as instrument.

Our results suggest that overeducation leads to lower wages among doctoral recipients while the same does not apply to overskilling. Genuine over-education is particularly detrimental for individual wages. It leads to a wage penalty of about between $23 \%$ and $25 \%$, more than twice bigger than what is found for overeducation alone.

The outline of this paper is as follows. Section 1 motivates the paper by documenting the explosion of Ph.D. graduates in Italy and the contemporary evolution of demand. Section 2 reviews the existing literature on the overeducation of Ph.D. holders. Section 3 illustrates the data used in the empirical analysis. Section 4 describes the methodology used in the estimates to control for endogeneity. Section 5 presents the main results of the analysis. Some concluding remarks follow.

\section{Motivation}

Doctoral education was set in Italy in $1980^{1}$ and the first Ph.D. titles were awarded in 1985 (Ballarino and Colombo, 2010). According to the available data presented in Figure 1, the yearly number of new Ph.D. holders in Italy (all fields of study considered) has been quite stable until the beginning of the 1990s. Since then, it has recorded a slight increase over the 1990s while an impressive expansion started from the beginning of the 2000s. Indeed, over the period 2002-'12 the yearly number of new doctoral recipients triplicated and reached 12,000.

International comparisons reveal that this growth was particularly steady. Data collected for the period 1998-2006 (Auriol, 2010) shows that in Europe only Portugal and the Slovak Republic reported a higher increase in the annual growth of doctoral degrees awarded. Nevertheless, the 2011 Italian graduation rate at doctoral level, as a percentage of population in the reference age cohort, was still lower than the OECD average (OECD, 2013).

\section{[Figure 1 about here]}

This remarkable expansion of the number of Ph.D. holders has generated much concern about the employability of new doctoral graduates and about the existence of working opportunities suitable for people who are specifically trained in carrying out $R \& D$. This concerns are motivated

\footnotetext{
${ }^{1}$ Decree of the President of the Republic n. 382, 11 November 1980.
} 
by data reported in Figure 2 which shows that both in 2002 and in 2012 the number of people employed in R\&D activities was definitely lower than the UE average, even if on the rise.

The size of the Italian academic sector and its evolution over the 2000 s suggests that Universities cannot be considered as the main professional destination for most of these new doctoral recipients. This is consistent with the idea that doctoral studies are a third-cycle education (Berlin Communiqué, 2003) and, therefore, shall prepare for professional activities to be carried out in various sectors also outside higher education. Figure 3 shows the total number of Assistant Professors (first step of the academic career) and the total personnel (Assistant Professors + Associate Professors + Full Professors) hired by Italian Universities over 2002-'14. While total personnel definitely decreased over the 2000 s ( $-9 \%$, approximately $-6,000$ positions), a $16 \%$ increase (approximately 3,500 new positions) is reported for Assistant Professors over 2002-'12, but this period is followed by a severe decline in 2013-`14.

\section{[Figure 2 and 3 about here]}

In the Italian Public Administration (PA), R\&D personnel remained quite stable over the 2000s (Figure 4) and this suggests that also PA cannot be considered as a crucial destination for new Ph.D. holders.

R\&D in private enterprises, instead, reveals some dynamism over the 2000 s. Indeed, after a small decline in 2002-2004, the number of people that the private sector employed in R\&D has moved from about 70,000 in 2002 to about 120,000 in 2012. Still it is a matter of concern whether the private sector has been able to provide jobs that are fully exploiting the skills of Ph.D. graduates.

According to evidence provided in Gaeta (2013 and 2015) and in Gaeta and Lubrano Lavadera (2016), employability of doctoral graduates is rather high in Italy since 3-5 years after graduation only $7 \%$ is still unemployed. Nevertheless, approximately $20 \%$ of doctoral recipients report that their Ph.D. was not useful to get the job they hold a few years after completing their doctoral studies and $46 \%$ report that their doctoral competences are not used in the job they carry out.

\section{[Figure 4 about here]}

\section{Overeducation and wages: literature review}

We apply to the case of Ph.D. holders the econometric methodology developed for the case of university graduates (for recent surveys of this latter literature, see, among others, Leuven and Oosterbeek, 2011; Caroleo and Pastore, 2016). Different sources of bias may arise when estimating the wage effect of overeducation by OLS. While endogeneity tends to generate upward corrections of the wage penalty, and measurement errors a downward correction, the direction of bias associated to sample selection is ambiguous. Considering the low share of non-employed (unemployed and inactive) among Ph.D. holders in our data, our discussion will focus essentially on endogeneity issues.

Measurement errors, due to the fact that overeducation is self-reported, tend to reduce the wage penalty associated to overeducation as estimated by OLS since often individuals believe, subjectively, more than they do objectively, to be overeducated (or also overskilled) when they 
are not. The downward bias is due to the fact that OLS considers as overeducated also individuals who are not genuinely overeducated. It is important to detect the cases of measurement errors to understand whether and how many individuals are actually overeducated and how many are not. In fact, the measurement of overeducation as based on statistical methods shows that undereducation is also possible among university graduates, though not among Ph.D. holders. Chevalier (2003) is the first contribution to propose detecting genuine overeducation by interacting the self-reported educational mismatch status with the level of job satisfaction. Mavromaras et al. (2010) and Pecoraro (2011) elaborate on this early idea by suggesting that it would be more appropriate to use as a screening device the degree of satisfaction regarding the type of skill matching that the individual reports.

Endogeneity bias arises if overeducation is related to unobserved individual characteristics, such as a lower level of skills and motivation of the overeducated. Now, if the overeducated are less motivated, talented and skilled than average, it is likely that the wage penalty estimated by OLS be under-estimated in absolute value. In fact, once controlling for unobserved lower motivation and skills with appropriate methodologies, either panel data analysis with fixed effects or instrumental variables in case of cross-sectional data, the coefficient of overeducation should be lower (bigger in absolute value).

A specificity of the skill market of Italy is its low level of both demand and supply. From the demand side, Manacorda and Petrongolo (2000), among others, note that the production structure is still based on labour intensive traditional manufacturing. Therefore, the origin of the educational mismatch could be found in the weak demand of more educated workers as compared to the skills supplied by the educational system (Cainarca and Sgobbi, 2009). From the supply side, Checchi (2003), Caroleo and Pastore (2012) and Franzini and Raitano (2012), among others, note the lowest level of educational attainment of young people as compared to the EU average.

A recent and growing strand of literature points to the inefficiency of the educational system in generating a sufficient level and right composition of skills to match the need of labour demand, due to the lack of work-related skills that the education system tends to generate (Caroleo and Pastore, 2013; 2016).

All this considered, in principle, it is hard to say whether overschooling is in Italy higher or lower than elsewhere. Different measures lead to different conclusions. ISTAT estimated that the undereducated were 1.9 millions ( $9 \%$ of employment), whereas the overeducated amounted to 3.7 million (16.5\%) in 2006. The existing comparative evidence hints that the country has a higher than average share of overeducated workers, suggesting that demand is more at risk of losing the race with the supply of human capital than elsewhere. Horizontal overeducation might also be an important component, due to the low degree of orientation of high school diploma students, the scant integration of the educational system with the labour market and the high share of graduates in humanities and other arts degrees. In their study of the REFLEX data, McGuinness and Sloane (2010, Table 3.6) find that the extent of the educational mismatch is in Italy one of the highest among the EU countries included in their sample. Slightly different is the case of overskilling, which is much more common in the REFLEX sample and for which Italy tends to the sample average. 
The wage penalty of overeducated or overskilled university graduates is found to be lower in Italy than in other countries and in some cases not statistically significant (for a review of these findings, see Caroleo and Pastore, 2013). Cutillo and Di Pietro (2006) find a wage penalty for university graduates ranging between $2.4 \%$ and $5.7 \%$ in simple OLS estimates based on an ISTAT database of 2001 graduates. McGuinness and Sloane (2010) find a wage penalty of about 10\%. Interestingly, in the case of Italy, they find a higher wage penalty for the overskilled $(-11 \%)$ than for the overeducated $(-4 \%)$, the latter being not statistically significant. Caroleo and Pastore (2013) find a conditional wage penalty equal to $12 \%$ for overeducation and to $7 \%$ for overskilling by using the largest data set of graduates in Italy (AlmaLaurea) interviewed 5 years from their graduation. Once controlling for sample selection bias, the penalty goes up, but only by little.

Using the ISFOL PLUS data, Aina and Pastore (2012) find a strong correlation of overeducation with delayed graduation and a wage penalty associated to overeducation of about $20 \%$, slightly higher than in previous studies.

The low wage penalty associated to the educational and skill mismatch in Italy suggests that firms have strong incentives to hire a worker holding a university degree rather than an individual holding a high secondary school diploma even if the university graduate is bound to remain overeducated. This can be understood considering the highest unemployment rate existing traditionally in the country and the abundance of non-employed job seekers especially among the youngest segments of the population. Although lower than that among young people holding a high school diploma, the unemployment rate of university graduates is higher in Italy than in other EU countries. It is perfectly compatible with a job competition model whereas university degrees are achieved as a tool to compete for the few jobs available in the labor market.

Once controlling for the endogeneity of overeducation, Cutillo and Di Pietro (2006) find that the wage penalty increases up to between 22 and 39\%. Once controlling for both endogeneity and sample selection bias, the wage penalty of overeducation reaches about $40 \%$.

Research on over-education among Ph.D. holders is only at its infancy stage. To the best of our knowledge the number of contributions covering this issue is limited and relevant papers have been published only rather recently.

Bender and Heywood (2009) provide the first analysis of overeducation among doctoral graduates. Their study uses survey data collected between 1997 and 1999 to analyse the career outcomes of Ph.D. holders who obtained their title in the USA and specialized in a wide set of fields of study. In order to assess the Ph.D. - job mismatch, they rely on a primary indicator which is built by looking at respondents self-evaluations of the consistency between the job they carry out and the doctoral degree they achieved. Alongside this indicator, they rely on two secondary indicators. One was built by looking at respondents' assessments of the consistency between expectations upon completing the doctoral degree and the job they carry out some years later. A second one, instead, is based on respondents opinions about the goodness of their field of study choice.

According to their data, mismatch is more likely to occur in the non-academic sector (43.6\% declared that their job is not very closely related to their education) than in the academic one (16.\%). Furthermore, they observe a high heterogeneity in the overeducation incidence among fields of study; Computer Science, Management and Health are those majors that report the highest share of not perfectly matched doctorate holders. 
Looking more specifically at the wage effects of overeducation among Ph.D. holders, their crosssectional estimates, which are not corrected for the potential endogeneity of overeducation, report that over-educated individuals approximately earn between $7 \%$ and $13 \%$ less than their well-matched colleagues, according to sectors of employment. The existence of a wage penalty of overeducation is confirmed by a fixed effect panel data analysis whose results, nevertheless, suggest that the impact of overeducation is roughly half than the one found through cross sectional estimates. This result, has to be taken with extreme caution since specifications implemented in a cross-sectional and in a panel context notably differ.

Di Paolo and Mané (2014) provide an empirical study focused on a survey of doctoral recipients from the Catalonia region of Spain that has been carried out in 2011 and included a sample of individuals who obtained a Ph.D. diploma 4/ 5 years earlier. Their analysis includes two measures of overeducation that are respectively based on respondents' self-assessment of the usefulness of their Ph.D. title to get their current job and on the usefulness of their Ph.D.-specific skills in their current job. According to the findings they report, approximately $28 \%$ of respondents were not adequately matched in terms of skills while $47 \%$ of them were not adequately matched in terms of qualifications.

Both these overeducation measures as well as their interaction were included as regressors when estimating wages. According to these estimated results, which do not take into account potential endogeneity, only those Ph.D. holders who are both over-educated and over-skilled report a significant income penalty (approximately $-11 \%$ ).

Research on Italian Ph.D. data has boosted only in recent years thanks to the availability of micro data provided by extensive surveys carried out by the Italian National Institute of Statistics (ISTAT). The 2009 survey, which is the one most used in the literature, includes doctoral graduates who completed their study few years before, in 2004 or 2006.

By using this data, Gaeta (2013) analyses Ph.D. holders' satisfaction for the use of skills acquired during the doctoral education and found that approximately $25 \%$ of respondents are totally dissatisfied with the use of their doctoral skills. Gaeta (2015) reveals that the share of doctorate holders who declare that their title was not useful to get their current job is $19 \%$ while those who report that their Ph.D skills are not useful in order to carry out their current job is markedly higher (over 40\%).

Gaeta and Lubrano Lavadera (2016) provide insights concerning the wage consequences of holding a job which has been obtained without relying on the Ph.D. title. Their analysis takes into account the potential endogeneity of overeducation and shows that the wage penalty of overeducation is approximately $9 \%$ but highly varies according to the time of graduation, since it is higher for more recent graduates, and according to the field of study, being notably higher for fields of study such as Social Sciences and Humanities.

\section{Data}

Our analysis is based on data provided by the cross-sectional survey of Italian PhD holders that ISTAT carried out in 2009. To the best of our knowledge, cross-sectional data are the only 
available ones for Ph.D. holders in Italy. The ISTAT survey involved all Ph.D. holders $(\mathrm{n}=8814)$ who completed their studies in Italy and in all the existing fields of research in 2004 or in 2006. According to their year of doctoral graduation, they were interviewed three or five years after their graduation The survey is highly representative of the whole population since it covers approximately $50 \%$ of it.

Among the rich set of variables that are available in the database, there are also data concerning the respondents' self-assessment of their working conditions and measures of their net hourly wage. According to the data, most of the respondents were employed at the time of the interview $(93.05 \%)$, which suggests that there is only little self-selection into employment. This nonemployment figure is particularly low. Indeed, the Istat (2009) suggests that in 2007 the unemployment rate among university graduates that completed their studies three years before was approximately $14 \%$ and $16 \%$ according to whether M.Sc. or BA is considered. 2007 was a pre-economic crisis year and this suggests that the employment differential between university graduates and Ph.D. holders may be even higher than the one reported.

Looking at those Ph.D. holders in our survey who declared to be employed, the average net hourly wage is $€ 10.77$; while the average net monthly wage is about $€ 1500$. Again, this figure is higher than the one reported by university graduates interviewed in 2007, which amounted approximately to $€ 1300$ euros per month (Istat, 2009).

With the purpose of investigating the wage effect of overeducation, the net hourly wage is set as the dependent variable in a Mincer-type regression model where a dichotomous measure of overeducation is included among covariates.

In order to provide robust insights concerning the wage effect of overeducation, we relied on different definitions of overeducation. First, we used the respondents' self-assessment of overeducation that is based on a specific question included in the survey: "In order to get your current job, was your Ph.D. title explicitly required, was it at least useful or was it totally useless?" Answers to this question were coded into a dummy variable that takes the value of one when respondents declare that their Ph.D. title has been unrequested and totally useless (this variable is labeled OVEREDUCATION in the following analyses).

Second, we relied on a variable that more specifically focuses on the concept of overskilling. This variable observes respondents' self-assessment of the usefulness of skills acquired during their Ph.D. training when carrying out their current job. The following question in the survey covers this specific aspect. "Are the skills acquired during your Ph.D. studies essential in order to carry out your current job?" Possible answers to this questions are coded into a dummy variable that takes the value of one for those who declared that there is no match between skills and current job. This variable is labelled OVERSKILLING hereafter.

Third, by following Mavromaras et al (2013) and Pecoraro (2014), we interacted OVEREDUCATION and OVERSKILLING in order to create four categorical variables that allows us distinguishing four hypothetical situations. Firstly, genuine matching (GM) arises when respondents declare themselves to be neither overeducated nor overskilled. Secondly, apparent matching (AM) arises when respondents declare to be not overeducated but to be overskilled. Thirdly, apparent overeducation (AO) arises when respondents declare to be overeducated but 
not overskilled. Finally, genuine overeducation (GO) is the condition arising when both overeducation and overskilling are simultaneously reported.

Table 1 shows the interaction between overeducation and overskilling in our sample. GM is the most frequent self-reported condition in the sample under investigation but still only $52.1 \%$ of the Ph.D. holders surveyed declare it. By contrast, 17.3\% of the sample reports to be in a GO condition. AM is still rather frequent, being reported by almost $28.8 \%$ of the surveyed Ph.D. holders, while $\mathrm{AO}$ is a definitely residual category that only concerns less than $2 \%$ of the respondents.

\section{[Table 1 about here]}

Fourth, by following Chevalier (2003) we built a categorical variable that is calculated by interacting OVEREDUCATION with another dummy (labelled JOB SATISFACTION) that measures respondents' satisfaction for the use of Ph.D. skills in carrying out their current job. The latter variable, is built by looking at one question in the ISTAT (2009) questionnaire that specifically asks to all those who hold a job "How much are you satisfied with the use of skills acquired during your Ph.D. studies?” Answers were coded into a dummy that takes the value of one in case of high or of average satisfaction and zero in the case of partial or total dissatisfaction.

The interaction between OVEREDUCATION and JOB SATISFACTION generates four alternative modalities that replicate those presented when looking at the interaction between OVEREDUCATION and OVERSKILLING. Genuine matching (GM) arises when respondents declare themselves to be not overeducated and to be satisfied for their use of skills. Apparent matching (AM) arises when respondents declare to be not overeducated but report to be unsatisfied with skills' use. Apparent overeducation (AO) arises when respondents declare to be overeducated but still satisfied for the use of their doctoral level skills. Genuine overeducation (GO) arises when overeducation and dissatisfaction are both simultaneously reported. Table 2 shows how overeducation and job satisfaction interact with each other in our sample.

\section{[Table 2 about here]}

GO presents an incidence (3.6\%) smaller compared with the one calculated when looking at the overeducation/overskilling interplay $(17.3 \%)$. The incidence of GM appears to be the higher part of interviewed in both Table 2 and. Indeed, according to Table 2, when job satisfaction for the use of skills is taken into account, the $73.8 \%$ of respondents self-report to hold a job genuinely matched with their background. This share is definitely higher than the one found when the overeducation/overskilling interplay is considered to identify genuine overeducation.

Moving from these alternative definitions of the overeducation condition, our empirical investigation is based on the estimate of Mincer-type regressions whose objective is to investigate the link existing between each of them and respondents' hourly wages.

Table 3 provides descriptive statistics regarding our dependent variable, the logarithm of hourly wages, and the independent variables of interest, including the aforementioned overeducation variables. Table A1 in the Annex provides the variables' definition.

\section{[Table 3 about here]}


Control variables are grouped in six classes. Socio-economic variables are all dichotomous, the age of achieving their $\mathrm{PhD}$ is divided in 5 dichotomous variables from less than 30 years to 33 years and more. FEMALE defines gender, MARRIED and CHILDREN represent PhD holders' family status if they are married and they have one or more children. PARENTLIVE means that the interviewed is living with her parents. HIGHFAMILYGRADE is the highest parents' education title.

We control for all fields of study and geographical regions. In Italy scientific fields are grouped in 14 classes and we create a dummy variable for each of them. We left out Maths field. They are distinguished from hard sciences, Engineering and social sciences. The Italian territory is divided in four macro-regions, namely North-East, North-West, Centre and South, the baseline being represented by all $\mathrm{PhD}$ holders living out of Italy.

To catch some specific features of the activities carried out during the $\mathrm{PhD}$, we include three dummy variables indicating if the interviewed attended a WORKSHOP, a SUMMERSCHOOL and/or other COURSES. TAUGHT indicates if they taught in an undergraduate class at their university. GRANT2 represents if the $\mathrm{PhD}$ received a grant during their doctoral studies; the variable OTHERFINIMP equals one if they received some other form of financial support. Obviously, receiving a grant means having more time to spend on research. EXTENSION indicates if the $\mathrm{PhD}$ needed a time extension to obtain the title, additional to the curricular 3years. YEAR represents if the PhD was obtained in 2004 or in 2006.

We control for educational performance before beginning the PhD. FROMDTOPHD is a count variable that measures the years from graduation to the beginning of the PHD. On average, a $\mathrm{PhD}$ begins after 2 and a half years after graduation with a standard deviation of 2 years and half that means that the greatest part of $\mathrm{PhD}$ start immediately or in the first five years from graduation. Our survey does not ask for a graduation score, but it divides scores in 5 groups, each represented by a dummy variables. The greatest part of $\mathrm{PhD}$ holders $(70 \%)$ are in the highest score categories.

We control also for some job features. We have a distinction of the job macro-sector, mainly ACADEMY if they work in a University and if they teach at University (TEACHING). If they work in MANUFACTURE, SERVICES or AGRICULTURE. Some specific features as if they are SELFEMPLOYED, employed in a PERMANENT job or a PARTIME job. We also identify whether their job is totally (ONLY RD), partially (PARTIALLY RD) or not at all (NOT AT ALL) in the R\&D sector. We also have some information about the productivity level as measured by the number of publications, patent and other scientific products after reaching the $\mathrm{PhD}$ title. Moreover, there is also a proxy to measure the years of work experience after completing their PhD (WKEXPYR) and if they worked a year after gaining their title (PhDYRJOB). Finally, a dichotomous variable refers to the fact whether they moved to a different province from that where they obtained their $\mathrm{PhD}$ after gaining their title (MIGRANT).

\footnotetext{
${ }^{2}$ In Italy, almost 50\% of the PhD candidates receive a 3-year grant from Government. The annual gross amount of Ph.D. grants is equal to $€ 13.638,47$, which includes in recent years also social security contributions.
} 


\section{Methodology}

In order to estimate the effect of overeducation on hourly wages in a cross-sectional dataset, one has to bear in mind that endogeneity may bias an OLS estimate of any Mincer-type regression where overeducation is considered among covariates. Indeed, there are reasons to believe that unobserved factors may exert a significant influence on both the probability of being in the overeducation status and the wage earned. This is the case, for example, of unobserved individual ability that conditions wages and, at the same time, is presumed to have an impact on the probability of falling and remaining in an overeducated job position.

Even if the ISTAT survey makes available an impressive number of individual characteristics of respondents, and this allows us considering a number of relevant covariates in the OLS estimates of wages, the endogeneity problem arising from omitted variable bias may not be totally ruled out.

In order to face it, we provide an estimate of the causal effect of overeducation (in its alternative definitions presented in the previous section) on wages by using a instrumental variable (IV) econometric approach. To illustrate the impact and direction of the IV correction, we present the OLS estimates for comparison.

A reliable instrument must simultaneously respect two conditions; on the one hand, it must be correlated with the endogenous variable after controlling for other exogenous and confounding factors. which is usually referred to as the relevance condition. On the other hand, it must exert its influence on the outcome variable only through the endogenous variable; in other words, it must be uncorrelated with errors resulting from the wage equation.

Bearing in mind these two requirements and following Gaeta and Lubrano Lavadera (2016), for each of the alternative definitions of overeducation our empirical analysis uses as instrument its incidence among those respondents who share the same residence and the same field of study of the observed individual.

Our regression approach can distinguish two main cases. Firstly, we regress the logarithm of hourly wages on a single endogenous variable. These are the cases considering OVEREDUCATION, GO (Genuine Overeducation) and OVERSKILLING or SATISFACTION. In this case we have a single instrumental variable for each case. Alternatively, when we have three endogenous variables - AM, AO and GO -, we use three instrumental variables. We use as instrument the incidence of respondents for each endogenous variable by place of residence and field of study.

All the tests run in order to support the econometric robustness of our instrumental variables, are reported at the bottom of the tables and provide positive results. In the case of a single instrument, we added three relevant tests to each regression. The first stage regression test (FSTAGE) measures the correlation between the endogenous variable and the instrument used in the estimates (Stock et al., 2002). If the instrument is weakly correlated, then we need more instruments. We tested for weak correlation (WEAK IV) and rejected this hypothesis in all cases. Finally, we test for the endogeneity of the instrumental variables on the principal regression (ENDOGE) and rejected the hypothesis of endogeneity in all our specifications (Baum et al., 2003). In the case of multiple instruments for multiple endogenous variables, we can test only 
the first stage regression test (FSTAGE) and we may implement the endogenous test (ENDOG) (Cameron and Trivedi, 2005, p. 276). Also in this case the robustness of our analysis is confirmed.

Once endogeneity has been taken into account, there are two more caveats to be considered. First, correlations among regressors have to be inspected in order to avoid the risk of high collinearity. To avoid this problem we test for variance inflation factor (VIF). Our results are under the critical threshold of 10. Secondly, since non-employed respondents are excluded from the sample under investigation, one has to check whether this exclusion leads to any sample selection bias. Even if the unemployed are a small percentage of the whole sample (6.9\%) and this suggests that the sample selection bias should not be particularly sizeable, we estimated a Heckman sample selection model (Heckman, 1979) and 2SPS to control for sample selection. We did not find any significant dependence of our estimates form the sample under analysis and therefore omit to report the results for shortness' sake ${ }^{3}$.

\section{Results}

\subsection{Wage impact of GO as resulting from the interplay between overeducation and overskilling}

Table 4 reports results obtained when OVEREDUCATION, OVERSKILLING and their interplay are considered to measure Ph.D. holders' education-job mismatch and estimate its impact on hourly wage, which is the dependent variable. A number of alternative models are presented, according to the different definitions of overeducation considered. For each definition of overeducation, the OLS and the IV estimate of its impact on wages is reported. The tests used in order to assess the validity of the instruments adopted in the IV regression analyses are reported at the bottom of the table. As explained in the previous section, they all support our econometric approach and, hence, for shortness' sake, will not be discussed further in what follows.

\section{[Table 4 about here]}

Model (1) shows the results obtained when OVEREDUCATION is used among the regressors alongside the other control variables. It replicates the estimates provided by Gaeta and Lubrano Lavadera (2016) on the same data. The OLS estimates show that overeducation has a negative and statistically significant correlation with wages; furthermore, the IV estimates purport the view that that this correlation has to be interpreted as a causal impact. The latter estimates provide evidence that the overeducated Ph.D. holders in our sample earn approximately $10 \%$ less than their well matched counterparts. The size of the IV estimated coefficient is lower than the one found through OLS even if the difference is not sizeable. This suggests that the omitted variable problems determined some up warding bias in the OLS estimates. The wage penalty found in this analysis is not much different from the one found among university graduates, which has been reported in the survey of the literature provided in section 2 . Such a size of the gap between overeducated and well matched individuals should not be understated, in a country where the wage structure is typically compressed because of collective agreements and other pervasive systems of wage fixing (Brunello, Comi, Lucifora, 2001).

\footnotetext{
3 The results are available on request from the authors.
} 
In model (2) the interplay between OVEREDUCATION and OVERSKILLING is considered. Coefficients calculated for AM, AO and GO have to be considered as the impact of these conditions on hourly wages compared with GM, which is treated as the reference category. As in the case of model (1) both OLS and IV estimates are presented. In the IV estimates we did not distinguish the three IV variables with respect to the three endogenous variables considered.

Among the regressors, we are mainly interested in the overeducation regressors. The coefficient of GO is the only one to be highly significant from a statistical point of view in the OLS estimates. According to this result, there is a negative correlation between genuine overeducation and wages. Nevertheless, this finding is not supported by the IV estimates. Indeed, they provide coefficients signs for AM, AO and GO which are in line with Pecoraro (2013) but no one of these variables turns out to be statistically significant.

Model (3) includes only GO among the overeducation battery of variables. The coefficient calculated for this variable has to be intended as the wage penalty determined by GO as compared with all the other possible conditions (GM, AM, AO). Again, both OLS and IV estimates are presented. In the OLS estimate the wage penalty of GO is found to be approximately equal to $12 \%(\mathrm{p}<0.001)$ while the IV-estimated coefficient of overeducation is slightly lower but still sizeable, being approximately $-10 \%(\mathrm{p}<0.1)$. This is very close to what has been found for OVEREDUCATION in model (1). In this perspective, most of the wage penalty associated to overeducation in the first specification comes from GO.

Model (4) reveals that the same does not apply to OVERSKILLING. Indeed, this variable does not show any statistically significant impact on wages, neither in the OLS nor in the IV estimates. According to these results, a wage penalty exists only when the Ph.D. title is not useful to get the job while the use of Ph.D. skills does not matter in determining wages.

For shortness' sake, we omit to comment on the coefficients of control variables. In addition to being self-evident, these findings are not the main focus of the analysis. In any case, the expectations about the sign of the coefficients are all fulfilled.

\subsection{Wage impact of GO as resulting from the interplay between overeducation and skills' use satisfaction}

Table 5 provides IV estimates obtained when the definition of overeducation is identified by looking at both OVEREDUCATION and JOB SATISFACTION. As for tab. 4, also in this table a number of models are presented according to the different definitions of overeducation used as regressors.

As earlier, model (1) replicates the estimates of the wage impact of overeducation as contained in Gaeta and Lubrano Lavadera (2016), which is reported for ease of comparison.

In model (2) the AM, AO and GO as resulting from the interplay between OVEREDUCATION and JOB SATISFACTION are used among the regressors. The OLS results reveal that a negative and highly statistically significant correlation exists between each of the statuses considered and wages. According to this result, AM, AO and GO are associated to lower wages than GM which is used as the reference category. The size of the estimated coefficients suggests that the wage penalty is higher for those who are in the GO condition $(-22 \%)$ and sensibly lower for those who are in the AO (-10\% approximately) and in the AM condition (-8\%). Nevertheless, 
the IV-estimated coefficients show that only GO exerts a causal effect on wages. This effect is found to be sizeable (-25\% approximately) and remarkably higher than the one found through OLS.

This finding is important for two main reasons. First, it suggests that, in fact, the wage penalty associated to overeducation in general is the algebraic sum of different effects that depend on the type of mismatch and that most of the wage penalty arises from a particular category of mismatched PhD holders, who appear to be particularly weak, namely those declaring to be GO. Second, the size of the penalty is such that it suggests that, in some cases, namely in cases of GO, the choice to invest in further education after achieving tertiary education may be problematic. This might explain why public contexts to assign $\mathrm{PhD}$ positions are seeing a smaller number of candidates.

This result is basically confirmed by model (3) where GO is the only status included among the regressors. Its coefficient estimated through OLS and IV is still highly statistically significant and its size is only slightly reduced. Overall, model (3) and (4) suggest that the simultaneous presence of overeducation and satisfaction for the use of Ph.D. skills at their job determines a wage penalty that is more than double than the one calculated for overeducation alone.

Finally, model (4) reveals that the degree of SATISFACTION associated to the skills acquired during the Ph.D. training alone has not any statistically significant impact on wages. This result is similar to the one obtained in Table 4 for OVERSKILLING and supports the idea that wages do not depend only on using the skills acquired during the Ph.D. studies.

\section{[Table 5 about here]}

\section{Concluding remarks}

The R\&D focused education provided by doctoral studies makes Ph.D. holders potential innovation-drivers and this induces to consider them as crucial actors in a knowledge economy.

Consistently with this perspective, if a Ph.D. holder cannot find a job that allows him to fully exploit his title and skills, this has to be considered detrimental for the society as a whole. Besides this, a growing strand of literature (see. for reference, the reviews by Leuven and Oosterbeek, 2011; and Caroleo and Pastore, 2016) suggests that being in an overeducation condition exerts a negative influence on individual returns to education, i.e. has a negative effect on wages.

This paper empirically analyzed the causal nexus between overeducation and wages among doctoral recipients who were surveyed in Italy in 2009, a few years after completing their studies.

By extending previous contributions devoted to this specific issue (Gaeta and Lubrano Lavadera, 2016), besides overeducation, our analysis has considered the case of genuine overeducation as resulting from the interplay between a self-reported assessment about the use of the doctoral title. In order to get the current job and two alternative measures of respondents' opinion concerning the use of doctoral skills in carrying out their job, of which one is based on a direct question and another one is based on self-reported satisfaction for this specific aspect of their job. 
Our instrumental variable estimates suggest that a $10 \%$ wage penalty is observed when the uselessness of doctoral skills in carrying out the current job is combined with the uselessness of the Ph.D. title in order to get the current job. This penalty is found to be more than double that size when skills' use is measured through Ph.D. holders satisfaction for such specific aspect of their job as being satisfied with the use of the doctoral skills acquired during their $\mathrm{PhD}$ training. The gap is mainly due to genuine overeducation and the actual size of the gap is greater than the positive gap between $\mathrm{PhD}$ holders and normal university graduates.

Over last 15 years doctoral education has notably expanded in OECD countries and the statistical data reports that in Italy this growth has been particularly impressive. In this perspective, our analysis provides some insights about the career outcomes of doctoral graduates in a context where such an expansion of doctoral studies has been observed.

According to our analysis, unemployment is not a great issue for Ph.D. recipients since its incidence is definitely lower than the one reported by university graduates. Overeducation, instead, is a more worrying issue, since $15 \%$ - 18\% of Ph.D. holders in our sample survey consider themselves as genuinely overeducated. Our estimates of the wage penalty arising from overeducation suggest that it is rather heterogeneous, being particularly sizeable (more than $20 \%$ ) when self reported satisfaction for the use skills acquired during the Ph.D. is used in order to identify the genuine overeducation status of respondents. These penalties are sizeable considering the compressed wage structure of Italy and also the fact that they are computed with respect to their pears, other Ph.D. holders.

Overall, this might sound as a warning for educational institutions tending to finance any kind of $\mathrm{PhD}$. It partly explains also the reducing number of candidates for a $\mathrm{PhD}$ position. 


\section{References}

Aina, C., Pastore F. (2012). Delayed Graduation and Overeducation: A Test of the Human Capital Model versus the Screening Hypothesis, IZA discussion paper, n. 6413.

Argentin, G., Ballarino, G., Colombo, S. (2014). Investire in formazione dopo la laurea: il dottorato di ricerca in Italia, Working paper n. 60, AlmaLaurea Inter-University Consortium.

Auriol, L. (2010). Careers of doctorate holders: employment and mobility patterns, STI

Working Paper 2010/4. Paris, OECD. Available at: http:/ /www.oecd.org/dataoecd/46/43/44893058.pdf (accessed 20 May 2016)

Ballarino, G., Colombo, S. (2010). Occupational outcomes of PhD graduates in Northern Italy. Italian Journal of Sociology of Education, 2(2).

Baum, C. F., M. E. Schaffer, Stillman, S. (2003). Instrumental variables and GMM: Estimation and testing. Stata Journal, 3(1): 1-31.

Bender, K. A., Heywood, J. S. (2009). Educational mismatch among Ph. Ds: determinants and consequences. In Science and engineering careers in the United States: An analysis of markets and employment, pp. 229-255. University of Chicago Press.

Berlin Comuniqué (2003). Communiqué of the Conference of Ministers responsible for Higher Education in Berlin on 19 September 2003.

Blundell, R., Dearden, L., Meghir, C., Sianesi, B. (1999). Human capital investment: the returns from education and training to the individual, the firm and the economy. Fiscal studies, 20(1), 1-23.

Brunello, G., S. Comi and C. Lucifora (2001). The Returns to Education in Italy: A New Look at the Evidence. In Harmon, C., I. Walker and N. Westergard-Nielsen (eds.), The Returns to Education in Europe, Edward Elgar.

Cainarca, G. C., Sgobbi, F. (2009). Quanto paga studiare: la relazione fra istruzione e retribuzione in Italia. Economia Politica, 26(1), 53-84.

Cameron, A. C., Trivedi, P.K. (2005). Microeconometrics: Methods and Applications. New York: Cambridge University Press.

Caroleo, F.E., Pastore, F. (2012). Talking about the Pigou Paradox. Socio-Educational Background and Educational Outcomes of AlmaLaurea, International Journal of Manpower, 33(1): 27-50.

Caroleo, F.E., Pastore, F. (2013). Overeducation at a Glance: Determinants and Wage Effects of the Educational Mismatch, Looking at the AlmaLaurea Data, IZA Discussion Paper, No 7788.

Caroleo, F.E., Pastore, F. (2016). Overeducation: A Disease of the School-to-Work Transition System, in G.L. Coppola and N. O'Higgins (eds.), Youth and their Future. Unemployment, Education and Health in Europe, Routledge, London and New York.

Checchi, D. (2003). The Italian Educational System: Family Background and Social Stratification, in ISAE (ed.), Monitoring Italy, ISAE, Rome.

Chevalier, A. (2003). Measuring over-education. Economica, 70(279), 509-531.

Cutillo, A., Di Pietro, G. (2006). The effects of overeducation on wages in Italy: a bivariate selectivity approach, International Journal of Manpower, 27(2): 143-168.

Di Paolo, A., Mane, F. (2014). Are we wasting our talent? Overqualification and overskilling among $\mathrm{PhD}$ graduates. Overqualification and Overskilling among $\mathrm{PhD}$ Graduates. XREAP Document de Treball n. 6.

Duncan, G., Hoffman, S. (1981). The incidence and wage effects of overeducation. Economics of Education Review, 1(1), 75-86. 
Franzini, M., Raitano, M. (2012). Few and underutilized? Overeducation of Italian graduates, in E. Mandrone E. (ed) Labour Economics: PLUS Empirical Studies, ISFOL, Temi e Ricerche 3, Ediguida, Cava dè Tirreni.

Freeman, R. (1976). The Overeducated American. New York: Academic Press.

Gaeta, G. L. (2013). Matching Advanced Studies to the Skills Required for Work: The Case of PhD. Graduates in Italy. Economia dei Servizi, 8(2): 177-188.

Gaeta, G. L. (2015). Was it worth it? An empirical analysis of over-education among PhD recipients in Italy. International Journal of Social Economics,42(3): 222-238.

Gaeta, G.L., Lubrano Lavadera, G. (2016). Over-education and wages among Ph.D. holders. An empirical investigation on Italian data. International Journal of Manpower (forthcoming).

Harmon, C., Oosterbeek, H., Walker, I. (2003). The returns to education:

Microeconomics. Journal of economic surveys. 17(2), 115-156.

Heckman, J. (1979). Sample selection bias as a specification error. Econometrica, 47(1): 153-161.

Istat (2009). Università e lavoro 2009, report available at http://en.istat.it/lavoro/unilav/unilav_2009.pdf [last access on 2/7/2016]

Leuven E., Oosterbeek H. (2011). Overeducation and Mismatch in the Labour Market, in E.A. Hanushek, S. Machin and L. Woessmann, Handbook of the Economics of Education, 4: 283326.

Manacorda, M., Petrongolo, B. (2000). Skill Mismatch and Unemployment in OECD Countries, Wirtschaftspolitische Blatter, 47(1): 72-82.

Mavromaras, K. G., McGuinness, S., O’Leary, N. C., Sloane, P. J., Wei Z. (2013). Job mismatches and labour market outcomes: Panel evidence on university graduates, Economic Record, 89(286): 382-395.

McGuinness, S., Sloane, P.J. (2010). «Educational / skill mismatch» nel mercato del lavoro dei laureate: un'analisi comparata, in AlmaLaurea, XII Rapporto sulla condizione occupazionale dei laureati. Investimenti in capitale umano nel future di Italia ed Europa, Il Mulino, Bologna, pp: 101115.

Musgrave, R.A. (1956). A multiple theory of budget determination. Finanzarchiv 333-343.

Musgrave, R.A. (1959). The Theory of Public Finance. McGraw-Hill Book Company, New York.

OECD (2013). OECD Science, Technology and Industry Scoreboard 2013, OECD Publishing: Paris.

Pecoraro, M. (2014). Is there Still a Wage Penalty for being Overeducated but well-matched in Skills? A Panel Data Analysis of a Swiss Graduate Cohort, Labour, 28(3): 309-337.

Psacharopoulos, G. (1994). Returns to investment in education: A global update. World development, 22(9), 1325-1343.

Psacharopoulos, G., Patrinos, H. A. (2004). Returns to investment in education: a further update. Education economics, 12(2), 111-134.

Sianesi, B., Reenen, J. V. (2003). The returns to education: Macroeconomics. Journal of economic surveys, 17(2), 157-200.

Stock, J. H., Wright, J.H., Yogo, M. (2002). A survey of weak instruments and weak identification in generalized method of moments, Journal of Business and Economic Statistics, 20(4): 518-529. 


\section{Appendix of Tables and Figures}

Tab. 1: Overeducation and overskilling (Absolute frequencies and \% (in parentheses)).

\begin{tabular}{|c|c|c|c|c|c|}
\hline OVEREDUCATION & \multicolumn{4}{|c|}{ OVERSKILLING } & TOTAL \\
\hline & 0 & & 1 & & \\
\hline 0 & $3084(52.1 \%)$ & $(\mathrm{GM})$ & $1705(28.8 \%)$ & $(\mathrm{AM})$ & 4789 \\
\hline 1 & $109(1.8 \%)$ & $(\mathrm{AO})$ & $1025(17.3 \%)$ & $(\mathrm{GO})$ & 1134 \\
\hline TOTAL & 3193 & & 2730 & & 5923 \\
\hline
\end{tabular}

Source: our elaboration on data from the ISTAT survey of doctoral recipients carried out in 2009.

Tab. 2: Overeducation and job satisfaction (Absolute frequencies and \% (in parentheses)).

\begin{tabular}{|c|c|c|c|c|c|}
\hline OVEREDUCATION & \multicolumn{4}{|c|}{ JOB SATISFACTION } & TOTAL \\
\hline & 0 & & 1 & & \\
\hline 0 & $413(6.9 \%)$ & $(\mathrm{AM})$ & $4370(73.8 \%)$ & $(\mathrm{GM})$ & 4789 \\
\hline 1 & $211(3.6 \%)$ & $(\mathrm{GO})$ & $923(15.6 \%)$ & $(\mathrm{AO})$ & 1134 \\
\hline TOTAL & 624 & & 5299 & & 5923 \\
\hline
\end{tabular}

Note: Job satisfaction equals 1 when the individual is satisfied with the type of matching that there is in her job with the skills acquired during the Ph.D. training; $O$ otherwise.

Source: our elaboration on data from the ISTAT survey of doctoral recipients carried out in 2009. 
Table 3: Summary statistics

\begin{tabular}{|c|c|c|c|c|}
\hline VARIABLES & MEAN & SD & MAX & MIN \\
\hline LNWAGE & 7.279 & 0.405 & 6.215 & 8.854 \\
\hline Hours & 38.173 & 11.960 & 70 & 1 \\
\hline Monthly net wage & 1579.632 & 747.2608 & 7000 & 500 \\
\hline Monthly net wage OVERSKILLED & 1473.766 & 755.6933 & 7000 & 500 \\
\hline Monthly net wage Matched & 1557.214 & 698.3919 & 7000 & 500 \\
\hline OVEREDUCATION & 0.191 & 0.393 & 0 & 1 \\
\hline OVERSKILLING & 0.449 & 0.497 & 0 & 1 \\
\hline $\mathrm{AM}$ & 0.193 & 0.395 & 0 & 1 \\
\hline $\mathrm{AO}$ & 0.012 & 0.111 & 0 & 1 \\
\hline $\mathrm{GO}$ & 0.116 & 0.321 & 0 & 1 \\
\hline JOB SATISFACTION & 0.833 & 0.373 & 0 & 1 \\
\hline $\mathrm{AM}$ & 0.047 & 0.211 & 0 & 1 \\
\hline $\mathrm{AO}$ & 0.105 & 0.306 & 0 & 1 \\
\hline $\mathrm{GO}$ & 0.024 & 0.153 & 0 & 1 \\
\hline IV OVEREDUCATION & 0.199 & 0.168 & 0 & 1 \\
\hline IV OVERSKILLING & 0.450 & 0.184 & 0 & 1 \\
\hline IV AM & 0.193 & 0.126 & 0 & 1 \\
\hline IV AO & 0.012 & 0.034 & 0 & 1 \\
\hline IV GO & 0.116 & 0.105 & 0 & 1 \\
\hline IV SATISFACTION & 0.833 & 0.129 & 0 & 1 \\
\hline IV AM & 0.047 & 0.066 & 0 & 1 \\
\hline IV AO & 0.105 & 0.102 & 0 & 1 \\
\hline IV GO & 0.024 & 0.045 & 0 & 0.667 \\
\hline AGECOMPLETE=LESS THAN 30\$ & 0.283 & 0.450 & 0 & 1 \\
\hline AGECOMPLETE=30 YEARS & 0.151 & 0.358 & 0 & 1 \\
\hline AGECOMPLETE=31 YEARS & 0.139 & 0.346 & 0 & 1 \\
\hline AGECOMPLETE=32 YEARS & 0.108 & 0.311 & 0 & 1 \\
\hline AGECOMPLETE=33 AND MORE & 0.319 & 0.466 & 0 & 1 \\
\hline FEMALE & 0.538 & 0.499 & 0 & 1 \\
\hline MARRIED & 0.607 & 0.488 & 0 & 1 \\
\hline CHILDREN & 0.365 & 0.482 & 0 & 1 \\
\hline PARENTLIVE & 0.138 & 0.345 & 0 & 1 \\
\hline MATH and STATISTICSS & 0.0351 & 0.184 & 0 & 1 \\
\hline PHYSICS and ASTRONOMY & 0.0537 & 0.225 & 0 & 1 \\
\hline EARTH and ENVIR. SC. & 0.0644 & 0.246 & 0 & 1 \\
\hline CHIMESTRY & 0.0313 & 0.174 & 0 & 1 \\
\hline BIOLOGICAL SCIENCE & 0.124 & 0.329 & 0 & 1 \\
\hline MEDICAL SCIENCE & 0.0909 & 0.287 & 0 & 1 \\
\hline AGRIC. and VETERINARY & 0.0803 & 0.272 & 0 & 1 \\
\hline ARCHITECTURE & 0.0912 & 0.288 & 0 & 1 \\
\hline ENGINEERING SCIENCE & 0.0575 & 0.233 & 0 & 1 \\
\hline HUMAN SCIENCE & 0.102 & 0.303 & 0 & 1 \\
\hline HISTORY and PHILOSOPHY & 0.0962 & 0.295 & 0 & 1 \\
\hline LAW & 0.0764 & 0.266 & 0 & 1 \\
\hline ECONOMICS and STATISTICS & 0.0643 & 0.245 & 0 & 1 \\
\hline POLITICAL SCIENCE & 0.0326 & 0.177 & 0 & 1 \\
\hline WORKSHOP & 0.910 & 0.287 & 0 & 1 \\
\hline COURSES & 0.808 & 0.394 & 0 & 1 \\
\hline SUMMERSCHOOL & 0.263 & 0.440 & 0 & 1 \\
\hline OTHERFINIMP & 0.151 & 0.358 & 0 & 1 \\
\hline TAUGHT & 0.338 & 0.473 & 0 & 1 \\
\hline FROMDTOPHD & 2.680 & 2.626 & 0 & 28 \\
\hline DEGREE 66-90S & 0.004 & 0.059 & 0 & 1 \\
\hline DEGREE 91-100 & 0.051 & 0.220 & 0 & 1 \\
\hline DEGREE 101-05 & 0.108 & 0.310 & 0 & 1 \\
\hline DEGREE 106-109 & 0.129 & 0.335 & 0 & 1 \\
\hline DEGREE 110 & 0.708 & 0.455 & 0 & 1 \\
\hline GRANT & 0.781 & 0.413 & 0 & 1 \\
\hline EXTENSION & 0.102 & 0.302 & 0 & 1 \\
\hline $\mathrm{YEAR}=2004 \sqrt{\mathrm{S}}$ & 0.446 & 0.497 & 0 & 1 \\
\hline
\end{tabular}




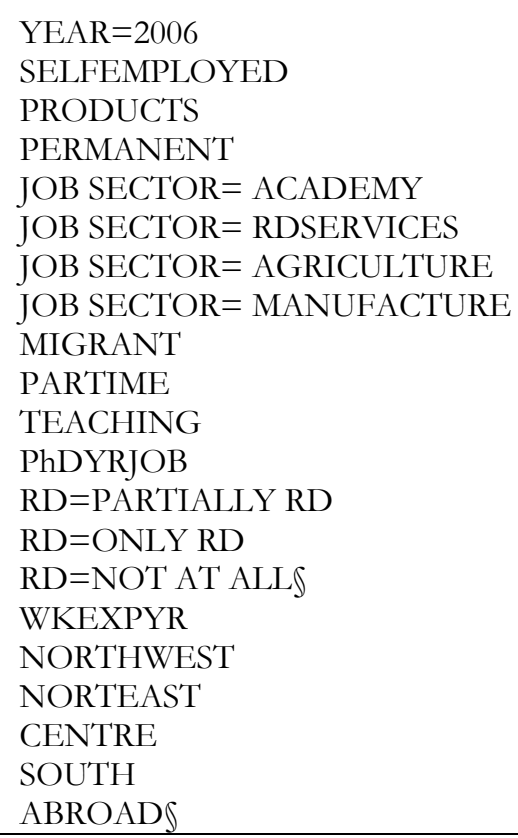

\begin{tabular}{|llll}
\hline 0.554 & 0.497 & 0 & 1 \\
0.136 & 0.343 & 0 & 1 \\
3.058 & 1.970 & 0 & 10 \\
0.396 & 0.489 & 0 & 1 \\
0.462 & 0.499 & 0 & 1 \\
0.567 & 0.495 & 0 & 1 \\
0.0160 & 0.125 & 0 & 1 \\
0.0773 & 0.267 & 0 & 1 \\
0.388 & 0.487 & 0 & 1 \\
0.103 & 0.304 & 0 & 1 \\
0.536 & 0.499 & 0 & 1 \\
0.822 & 0.383 & 0 & 1 \\
0.458 & 0.498 & 0 & 1 \\
0.241 & 0.428 & 0 & 1 \\
0.232 & 0.422 & 0 & 1 \\
1.994 & 1.850 & 0 & 6 \\
0.209 & 0.407 & 0 & 1 \\
0.166 & 0.372 & 0 & 1 \\
0.244 & 0.430 & 0 & 1 \\
0.318 & 0.466 & 0 & 1 \\
0.0630 & 0.243 & 0 & 1 \\
\hline
\end{tabular}

Note: Table A1 in the Annex provides the variables' definition. For shortness' sake, vertical lines besides the variables suggest which of them sum up to unity.

Source: our elaboration on data from the ISTAT survey of doctoral recipients carried out in 2009. Variables' definitions is provided in table $A 1$ in the annex. 
Table 4. Earnings equations. Wage effect with interaction of overeducation and overskilling

\begin{tabular}{|c|c|c|c|c|c|c|c|c|}
\hline & \multicolumn{2}{|c|}{$\begin{array}{c}\text { (1) } \\
\text { OVEREDUCATION }\end{array}$} & \multicolumn{2}{|c|}{$\begin{array}{c}(2) \\
\text { OVEREDUCATION* } \\
\text { OVERSKILLING }\end{array}$} & \multicolumn{2}{|c|}{$\begin{array}{c}\text { (3) } \\
\text { GENUINE } \\
\text { OVEREDUCATION }\end{array}$} & \multicolumn{2}{|c|}{$\begin{array}{c}(4) \\
\text { OVERSKILLING }\end{array}$} \\
\hline & OLS & IV & OLS & IV & OLS & IV & OLS & IV \\
\hline OVEREDUCATION & $\begin{array}{l}-0.118^{* * *} \\
(0.016)\end{array}$ & $\begin{array}{l}-0.101^{*} \\
(0.044)\end{array}$ & & & & & & \\
\hline $\mathrm{AM}$ & & & $\begin{array}{l}0.013 \\
(0.014)\end{array}$ & $\begin{array}{l}0.056 \\
(0.053)\end{array}$ & & & & \\
\hline $\mathrm{AO}$ & & & $\begin{array}{l}-0.063 \\
(0.043)\end{array}$ & $\begin{array}{l}-0.047 \\
(0.114)\end{array}$ & & & & \\
\hline GO & & & $\begin{array}{l}-0.116^{* * *} \\
(0.020)\end{array}$ & $\begin{array}{l}-0.061 \\
(0.069)\end{array}$ & $\begin{array}{l}-0.123^{* * *} \\
(0.017)\end{array}$ & $\begin{array}{c}-0.099^{*} \\
(0.048)\end{array}$ & & \\
\hline OVERSKILLING & & & & & & & $\begin{array}{l}-0.012 \\
(0.014)\end{array}$ & $\begin{array}{l}0.084 \\
(0.057)\end{array}$ \\
\hline 2006 & $\begin{array}{l}-0.041^{* * *} \\
(0.011)\end{array}$ & $\begin{array}{l}-0.042^{* * *} \\
(0.011)\end{array}$ & $\begin{array}{l}-0.042^{* * *} \\
(0.011)\end{array}$ & $\begin{array}{l}-0.042^{* * *} \\
(0.011)\end{array}$ & $\begin{array}{l}-0.042^{* * *} \\
(0.011)\end{array}$ & $\begin{array}{l}-0.042^{* * *} \\
(0.011)\end{array}$ & $\begin{array}{l}-0.043^{* * *} \\
(0.011)\end{array}$ & $\begin{array}{l}-0.044^{* * *} \\
(0.011)\end{array}$ \\
\hline NORTHWEST & $\begin{array}{l}-0.379^{* * *} \\
(0.023)\end{array}$ & $\begin{array}{l}-0.380^{* * *} \\
(0.023)\end{array}$ & $\begin{array}{l}-0.381^{* * *} \\
(0.023)\end{array}$ & $\begin{array}{l}-0.387^{* * *} \\
(0.024)\end{array}$ & $\begin{array}{l}-0.380^{* * *} \\
(0.023)\end{array}$ & $\begin{array}{l}-0.381^{* * *} \\
(0.023)\end{array}$ & $\begin{array}{l}-0.384^{* * *} \\
(0.023)\end{array}$ & $\begin{array}{l}-0.396^{* * *} \\
(0.024)\end{array}$ \\
\hline NORTEAST & $\begin{array}{l}-0.400^{* * *} \\
(0.023)\end{array}$ & $\begin{array}{l}-0.401^{* * *} \\
(0.023)\end{array}$ & $\begin{array}{l}-0.402^{* * *} \\
(0.024)\end{array}$ & $\begin{array}{l}-0.409^{* * *} \\
(0.025)\end{array}$ & $\begin{array}{l}-0.401^{* * *} \\
(0.023)\end{array}$ & $\begin{array}{l}-0.402^{* * *} \\
(0.023)\end{array}$ & $\begin{array}{l}-0.405^{* * *} \\
(0.024)\end{array}$ & $\begin{array}{l}-0.420^{* * *} \\
(0.025)\end{array}$ \\
\hline CENTRE & $\begin{array}{l}-0.384^{* * *} \\
(0.024)\end{array}$ & $\begin{array}{l}-0.385^{* * *} \\
(0.024)\end{array}$ & $\begin{array}{l}-0.386^{* * *} \\
(0.024)\end{array}$ & $\begin{array}{l}-0.392^{* * *} \\
(0.025)\end{array}$ & $\begin{array}{l}-0.386^{* * *} \\
(0.024)\end{array}$ & $\begin{array}{l}-0.387^{* * *} \\
(0.024)\end{array}$ & $\begin{array}{l}-0.389^{* * *} \\
(0.024)\end{array}$ & $\begin{array}{l}-0.401^{* * *} \\
(0.025)\end{array}$ \\
\hline SOUTH & $\begin{array}{l}-0.409^{* * *} \\
(0.024)\end{array}$ & $\begin{array}{l}-0.411^{* * *} \\
(0.024)\end{array}$ & $\begin{array}{l}-0.412^{* * *} \\
(0.024)\end{array}$ & $\begin{array}{l}-0.418^{* * *} \\
(0.025)\end{array}$ & $\begin{array}{l}-0.412^{* * *} \\
(0.024)\end{array}$ & $\begin{array}{l}-0.413^{* * *} \\
(0.024)\end{array}$ & $\begin{array}{l}-0.416^{* * *} \\
(0.024)\end{array}$ & $\begin{array}{l}-0.428^{* * *} \\
(0.025)\end{array}$ \\
\hline $\begin{array}{ll}\text { PHYSICS } & \& \\
\text { ASTRONOMY } & \end{array}$ & $0.073^{* *}$ & 0.046 & $0.073^{* *}$ & $0.072^{*}$ & $0.073^{* *}$ & $0.073^{* *}$ & $0.072^{*}$ & $0.070^{*}$ \\
\hline & $(0.028)$ & $(0.037)$ & $(0.028)$ & $(0.028)$ & $(0.028)$ & $(0.028)$ & $(0.028)$ & $(0.028)$ \\
\hline $\begin{array}{l}\text { EARTH \& } \\
\text { ENVIROMENTAL } \\
\text { SCIENCE }\end{array}$ & -0.015 & $0.119^{* * *}$ & -0.016 & -0.017 & -0.016 & -0.016 & -0.015 & -0.019 \\
\hline & $(0.026)$ & $(0.034)$ & $(0.026)$ & $(0.026)$ & $(0.026)$ & $(0.026)$ & $(0.026)$ & $(0.026)$ \\
\hline CHIMESTRY & $\begin{array}{l}0.024 \\
(0.034)\end{array}$ & $\begin{array}{l}0.031 \\
(0.033)\end{array}$ & $\begin{array}{l}0.023 \\
(0.034)\end{array}$ & $\begin{array}{l}0.021 \\
(0.034)\end{array}$ & $\begin{array}{l}0.023 \\
(0.034)\end{array}$ & $\begin{array}{l}0.023 \\
(0.034)\end{array}$ & $\begin{array}{l}0.020 \\
(0.035)\end{array}$ & $\begin{array}{l}0.016 \\
(0.035)\end{array}$ \\
\hline $\begin{array}{l}\text { BIOLOGICAL } \\
\text { SCIENCE }\end{array}$ & $-0.053^{*}$ & 0.070 & $-0.054^{*}$ & $-0.055^{*}$ & $-0.054^{*}$ & $-0.055^{*}$ & $-0.058^{*}$ & $-0.059^{*}$ \\
\hline & $(0.027)$ & $(0.039)$ & $(0.027)$ & $(0.026)$ & $(0.027)$ & $(0.026)$ & $(0.027)$ & $(0.026)$ \\
\hline $\begin{array}{l}\text { MEDICAL } \\
\text { SCIENCE }\end{array}$ & $\begin{array}{l}0.066^{*} \\
(0.031)\end{array}$ & $\begin{array}{l}-0.008 \\
(0.032)\end{array}$ & $\begin{array}{l}0.066^{*} \\
(0.031)\end{array}$ & $\begin{array}{l}0.063^{*} \\
(0.031)\end{array}$ & $\begin{array}{l}0.066^{*} \\
(0.031)\end{array}$ & $\begin{array}{l}0.065^{*} \\
(0.030)\end{array}$ & $\begin{array}{l}0.061^{*} \\
(0.031)\end{array}$ & 0.055 \\
\hline
\end{tabular}




\begin{tabular}{|c|c|c|c|c|c|c|c|c|}
\hline \multirow{2}{*}{$\begin{array}{l}\text { AGRICULTURE } \\
\text { VETERINARY }\end{array}$} & $\& \quad-0.011$ & $0.112^{* *}$ & -0.012 & -0.013 & -0.012 & -0.012 & -0.010 & -0.014 \\
\hline & $(0.030)$ & $(0.035)$ & $(0.030)$ & $(0.030)$ & $(0.030)$ & $(0.030)$ & $(0.030)$ & $(0.030)$ \\
\hline \multirow[t]{2}{*}{ ARCHITECTURE } & -0.033 & 0.036 & -0.034 & -0.034 & -0.034 & -0.034 & -0.035 & -0.036 \\
\hline & $(0.031)$ & $(0.034)$ & $(0.031)$ & $(0.031)$ & $(0.031)$ & $(0.031)$ & $(0.031)$ & $(0.031)$ \\
\hline \multirow{2}{*}{$\begin{array}{l}\text { ENGINEERING } \\
\text { SCIENCE }\end{array}$} & 0.054 & 0.013 & 0.054 & 0.053 & 0.054 & 0.054 & 0.054 & 0.052 \\
\hline & $(0.029)$ & $(0.035)$ & $(0.029)$ & $(0.028)$ & $(0.029)$ & $(0.028)$ & $(0.029)$ & $(0.029)$ \\
\hline \multirow[t]{2}{*}{ HUMAN SCIENCE } & -0.003 & $0.100^{* *}$ & -0.003 & -0.003 & -0.004 & -0.004 & -0.006 & -0.006 \\
\hline & $(0.031)$ & $(0.034)$ & $(0.031)$ & $(0.031)$ & $(0.031)$ & $(0.031)$ & $(0.031)$ & $(0.031)$ \\
\hline \multirow{2}{*}{$\begin{array}{l}\text { HISTORY } \\
\text { PHILOSOPHY }\end{array}$} & $\& \quad-0.042$ & 0.043 & -0.042 & -0.042 & -0.043 & -0.043 & -0.045 & -0.044 \\
\hline & $(0.029)$ & $(0.035)$ & $(0.029)$ & $(0.029)$ & $(0.029)$ & $(0.029)$ & $(0.029)$ & $(0.029)$ \\
\hline \multirow[t]{2}{*}{ LAW } & 0.025 & 0.004 & 0.025 & 0.025 & 0.025 & 0.024 & 0.020 & 0.021 \\
\hline & $(0.033)$ & $(0.034)$ & $(0.033)$ & $(0.032)$ & $(0.033)$ & $(0.032)$ & $(0.033)$ & $(0.033)$ \\
\hline \multirow{2}{*}{$\begin{array}{l}\text { ECONOMICS } \\
\text { STATISTICS }\end{array}$} & $\& \quad 0.025$ & 0.071 & 0.026 & 0.028 & 0.027 & 0.027 & 0.026 & 0.029 \\
\hline & $(0.030)$ & $(0.037)$ & $(0.030)$ & $(0.030)$ & $(0.030)$ & $(0.030)$ & $(0.030)$ & $(0.030)$ \\
\hline \multirow{2}{*}{$\begin{array}{l}\text { POLITICAL } \\
\text { SCIENCE }\end{array}$} & -0.046 & $0.072^{*}$ & -0.045 & -0.045 & -0.046 & -0.047 & -0.051 & -0.049 \\
\hline & $(0.037)$ & $(0.035)$ & $(0.037)$ & $(0.037)$ & $(0.037)$ & $(0.037)$ & $(0.037)$ & $(0.037)$ \\
\hline \multirow[t]{2}{*}{ WORKSHOP } & -0.014 & -0.014 & -0.014 & -0.013 & -0.013 & -0.013 & -0.014 & -0.013 \\
\hline & $(0.021)$ & $(0.021)$ & $(0.021)$ & $(0.021)$ & $(0.021)$ & $(0.021)$ & $(0.021)$ & $(0.021)$ \\
\hline \multirow{2}{*}{ COURSES } & 0.003 & 0.004 & 0.004 & 0.005 & 0.004 & 0.005 & 0.006 & 0.008 \\
\hline & $(0.014)$ & $(0.014)$ & $(0.014)$ & $(0.014)$ & $(0.014)$ & $(0.014)$ & $(0.014)$ & $(0.014)$ \\
\hline \multirow[t]{2}{*}{ SUMMERSCHOOL } & 0.008 & 0.008 & 0.008 & 0.010 & 0.008 & 0.008 & 0.009 & 0.012 \\
\hline & $(0.012)$ & $(0.012)$ & $(0.012)$ & $(0.012)$ & $(0.012)$ & $(0.012)$ & $(0.012)$ & $(0.012)$ \\
\hline \multirow[t]{2}{*}{ OTHERFINIMP } & 0.038 & 0.037 & 0.038 & 0.036 & 0.039 & 0.038 & 0.035 & 0.031 \\
\hline & $(0.020)$ & $(0.020)$ & $(0.020)$ & $(0.020)$ & $(0.020)$ & $(0.020)$ & $(0.020)$ & $(0.021)$ \\
\hline \multirow[t]{2}{*}{ TAUGHT } & -0.000 & -0.000 & -0.001 & -0.001 & -0.001 & -0.001 & -0.001 & -0.002 \\
\hline & $(0.011)$ & $(0.011)$ & $(0.011)$ & $(0.011)$ & $(0.011)$ & $(0.011)$ & $(0.011)$ & $(0.011)$ \\
\hline \multirow[t]{2}{*}{ FROMDTOPHD } & $0.033^{* * *}$ & $0.033^{* * *}$ & $0.033^{* * *}$ & $0.033^{* * *}$ & $0.033^{* * *}$ & $0.033^{* * *}$ & $0.033^{* * *}$ & $0.033^{* * *}$ \\
\hline & $(0.006)$ & $(0.006)$ & $(0.006)$ & $(0.006)$ & $(0.006)$ & $(0.006)$ & $(0.006)$ & $(0.006)$ \\
\hline \multirow[t]{2}{*}{ FROMDTOPHD2 } & -0.001 & -0.001 & -0.001 & -0.001 & -0.001 & -0.001 & -0.001 & -0.001 \\
\hline & $(0.000)$ & $(0.000)$ & $(0.000)$ & $(0.000)$ & $(0.000)$ & $(0.000)$ & $(0.000)$ & $(0.000)$ \\
\hline \multirow[t]{2}{*}{ DEGREE 91-100 } & 0.079 & 0.079 & 0.078 & 0.078 & 0.076 & 0.077 & 0.078 & 0.080 \\
\hline & $(0.096)$ & $(0.095)$ & $(0.096)$ & $(0.095)$ & $(0.096)$ & $(0.096)$ & $(0.095)$ & $(0.094)$ \\
\hline \multirow[t]{2}{*}{ DEGREE 101-05 } & 0.101 & 0.102 & 0.100 & 0.102 & 0.098 & 0.099 & 0.102 & 0.106 \\
\hline & $(0.095)$ & $(0.094)$ & $(0.095)$ & $(0.093)$ & $(0.095)$ & $(0.094)$ & $(0.093)$ & $(0.092)$ \\
\hline \multirow[t]{2}{*}{ DEGREE 106-09 } & 0.122 & 0.122 & 0.121 & 0.122 & 0.119 & 0.120 & 0.121 & 0.124 \\
\hline & $(0.094)$ & $(0.094)$ & $(0.094)$ & $(0.093)$ & $(0.095)$ & $(0.094)$ & $(0.093)$ & $(0.092)$ \\
\hline DEGREE 110 & 0.123 & 0.123 & 0.122 & 0.124 & 0.121 & 0.122 & 0.124 & 0.127 \\
\hline
\end{tabular}




\begin{tabular}{|c|c|c|c|c|c|c|c|c|}
\hline & $(0.094)$ & $(0.093)$ & $(0.094)$ & $(0.093)$ & $(0.094)$ & $(0.093)$ & $(0.092)$ & $(0.091)$ \\
\hline \multirow[t]{2}{*}{ GRANT } & 0.006 & 0.005 & 0.006 & 0.006 & 0.006 & 0.005 & 0.003 & 0.004 \\
\hline & $(0.015)$ & $(0.015)$ & $(0.015)$ & $(0.015)$ & $(0.015)$ & $(0.015)$ & $(0.015)$ & $(0.015)$ \\
\hline \multirow[t]{2}{*}{ EXTENSION } & 0.010 & 0.010 & 0.009 & 0.009 & 0.009 & 0.009 & 0.012 & 0.010 \\
\hline & $(0.019)$ & $(0.019)$ & $(0.019)$ & $(0.019)$ & $(0.019)$ & $(0.019)$ & $(0.019)$ & $(0.019)$ \\
\hline \multirow[t]{2}{*}{ GRADUATE } & 0.013 & 0.013 & 0.013 & 0.012 & 0.013 & 0.012 & 0.010 & 0.009 \\
\hline & $(0.013)$ & $(0.013)$ & $(0.013)$ & $(0.013)$ & $(0.013)$ & $(0.013)$ & $(0.013)$ & $(0.013)$ \\
\hline \multirow[t]{2}{*}{ Msc, MPhil OR PhD } & -0.005 & -0.005 & -0.005 & -0.005 & -0.005 & -0.005 & -0.007 & -0.007 \\
\hline & $(0.013)$ & $(0.013)$ & $(0.013)$ & $(0.013)$ & $(0.013)$ & $(0.013)$ & $(0.013)$ & $(0.013)$ \\
\hline \multirow[t]{2}{*}{30 YEARS } & 0.004 & 0.004 & 0.004 & 0.003 & 0.005 & 0.005 & 0.004 & 0.002 \\
\hline & $(0.015)$ & $(0.015)$ & $(0.015)$ & $(0.015)$ & $(0.015)$ & $(0.015)$ & $(0.015)$ & $(0.015)$ \\
\hline \multirow[t]{2}{*}{31 YEARS } & -0.023 & -0.023 & -0.023 & -0.024 & -0.022 & -0.023 & -0.025 & -0.027 \\
\hline & $(0.016)$ & $(0.016)$ & $(0.016)$ & $(0.016)$ & $(0.016)$ & $(0.016)$ & $(0.016)$ & $(0.016)$ \\
\hline \multirow[t]{2}{*}{32 YEARS } & -0.034 & -0.034 & -0.033 & -0.035 & -0.033 & -0.034 & $-0.036^{*}$ & $-0.039^{*}$ \\
\hline & $(0.018)$ & $(0.018)$ & $(0.018)$ & $(0.018)$ & $(0.018)$ & $(0.018)$ & $(0.018)$ & $(0.018)$ \\
\hline \multirow[t]{2}{*}{33 AND MORE } & $-0.040^{*}$ & $-0.040^{*}$ & $-0.039^{*}$ & $-0.039^{*}$ & $-0.039^{*}$ & $-0.039^{*}$ & $-0.039^{*}$ & $-0.038^{*}$ \\
\hline & $(0.019)$ & $(0.019)$ & $(0.019)$ & $(0.019)$ & $(0.019)$ & $(0.019)$ & $(0.019)$ & $(0.019)$ \\
\hline \multirow[t]{2}{*}{ MARRIED } & $-0.040^{*}$ & $-0.041^{*}$ & -0.013 & -0.012 & -0.013 & -0.013 & -0.014 & 0.011 \\
\hline & $(0.017)$ & $(0.016)$ & $(0.017)$ & $(0.017)$ & $(0.017)$ & $(0.017)$ & $(0.017)$ & $(0.017)$ \\
\hline \multirow[t]{2}{*}{ FEMALE } & -0.014 & -0.014 & $-0.040^{*}$ & $-0.039^{*}$ & $-0.040^{*}$ & $-0.040^{*}$ & $0.039^{*}$ & $0.039^{*}$ \\
\hline & $(0.017)$ & $(0.017)$ & $(0.016)$ & $(0.016)$ & $(0.016)$ & $(0.016)$ & $(0.016)$ & $(0.018)$ \\
\hline \multirow{2}{*}{$\begin{array}{l}\text { FEMALE } \\
\text { MARRIED }\end{array}$} & $-0.051^{* *}$ & 0.004 & $-0.050^{* *}$ & $-0.050^{* *}$ & $-0.050^{* *}$ & $-0.050^{* *}$ & $-0.051^{* *}$ & $-0.049^{* *}$ \\
\hline & $(0.016)$ & $(0.020)$ & $(0.016)$ & $(0.016)$ & $(0.016)$ & $(0.016)$ & $(0.017)$ & $(0.017)$ \\
\hline \multirow[t]{2}{*}{ CHILDREN } & $0.072^{* * *}$ & $0.072^{* * *}$ & $0.071^{* * *}$ & $0.071^{* * *}$ & $0.072^{* * *}$ & $0.072^{* * *}$ & $0.072^{* * *}$ & $0.070^{* * *}$ \\
\hline & $(0.013)$ & $(0.013)$ & $(0.013)$ & $(0.013)$ & $(0.013)$ & $(0.013)$ & $(0.013)$ & $(0.013)$ \\
\hline \multirow[t]{2}{*}{ PARENTLIVE } & $-0.046^{* *}$ & $-0.047^{* *}$ & $-0.047^{* *}$ & $-0.047^{* *}$ & $-0.047^{* *}$ & $-0.047^{* *}$ & $-0.048^{* *}$ & $-0.048^{* *}$ \\
\hline & $(0.017)$ & $(0.017)$ & $(0.017)$ & $(0.017)$ & $(0.017)$ & $(0.017)$ & $(0.017)$ & $(0.017)$ \\
\hline \multirow[t]{2}{*}{ PRODUCTS } & -0.002 & -0.002 & -0.002 & -0.001 & -0.003 & -0.002 & -0.002 & 0.000 \\
\hline & $(0.003)$ & $(0.003)$ & $(0.003)$ & $(0.004)$ & $(0.003)$ & $(0.003)$ & $(0.003)$ & $(0.004)$ \\
\hline \multirow[t]{2}{*}{ SELFEMPLOYED } & $-0.175^{* * *}$ & $-0.179^{* * *}$ & $-0.175^{* * *}$ & $-0.179^{* * *}$ & $-0.176^{* * *}$ & $-0.180^{* * *}$ & $-0.198^{* * *}$ & $-0.202^{* * *}$ \\
\hline & $(0.027)$ & $(0.029)$ & $(0.027)$ & $(0.029)$ & $(0.027)$ & $(0.029)$ & $(0.027)$ & $(0.028)$ \\
\hline \multirow[t]{2}{*}{ PERMANENT } & 0.013 & 0.012 & 0.014 & 0.013 & 0.013 & 0.012 & 0.005 & 0.005 \\
\hline & $(0.011)$ & $(0.011)$ & $(0.011)$ & $(0.011)$ & $(0.011)$ & $(0.011)$ & $(0.011)$ & $(0.011)$ \\
\hline \multirow[t]{2}{*}{ ACADEMY } & $-0.258^{* * *}$ & $-0.257^{* * *}$ & $-0.254^{* * *}$ & $-0.240^{* * *}$ & $-0.257^{* * *}$ & $-0.256^{* * *}$ & $-0.252^{* * *}$ & $-0.222^{* * *}$ \\
\hline & $(0.016)$ & $(0.016)$ & $(0.016)$ & $(0.023)$ & $(0.016)$ & $(0.016)$ & $(0.016)$ & $(0.024)$ \\
\hline \multirow[t]{2}{*}{ ONLY RD } & $-0.130^{* * *}$ & $-0.126^{* * *}$ & $-0.129^{* * *}$ & $-0.111^{* * * *}$ & $-0.133^{* * *}$ & $-0.127^{* * *}$ & $-0.105^{* * *}$ & $-0.070^{*}$ \\
\hline & $(0.019)$ & $(0.021)$ & $(0.020)$ & $(0.029)$ & $(0.019)$ & $(0.022)$ & $(0.019)$ & $(0.028)$ \\
\hline \multirow[t]{2}{*}{ PARTIALLY RD } & $-0.043^{*}$ & $-0.040^{*}$ & $-0.043^{*}$ & -0.036 & $-0.044^{* *}$ & $-0.040^{*}$ & -0.026 & -0.015 \\
\hline & $(0.017)$ & $(0.018)$ & $(0.017)$ & $(0.019)$ & $(0.017)$ & $(0.018)$ & $(0.017)$ & $(0.018)$ \\
\hline \multirow{2}{*}{ AGRICULTURE } & $-0.211^{* * *}$ & $-0.213^{* * *}$ & $-0.211^{* * *}$ & $-0.209^{* * *}$ & $-0.214^{* * *}$ & $-0.216^{* * *}$ & $-0.224^{* * *}$ & $-0.217^{* * *}$ \\
\hline & $(0.034)$ & $(0.034)$ & $(0.033)$ & $(0.034)$ & $(0.033)$ & $(0.033)$ & $(0.034)$ & $(0.035)$ \\
\hline
\end{tabular}




\begin{tabular}{|c|c|c|c|c|c|c|c|c|}
\hline MANUFACTURE & $\begin{array}{l}-0.074^{* * *} \\
(0.019)\end{array}$ & $\begin{array}{l}-0.075^{* * *} \\
(0.019)\end{array}$ & $\begin{array}{l}-0.074^{* * *} \\
(0.019)\end{array}$ & $\begin{array}{l}-0.074^{* * *} \\
(0.019)\end{array}$ & $\begin{array}{l}-0.075^{* * *} \\
(0.019)\end{array}$ & $\begin{array}{l}-0.076^{* * *} \\
(0.019)\end{array}$ & $\begin{array}{l}-0.080^{* * *} \\
(0.019)\end{array}$ & $\begin{array}{l}-0.078^{* * *} \\
(0.019)\end{array}$ \\
\hline \multirow{2}{*}{ MIGRANT } & $0.054^{* * *}$ & $0.055^{* * *}$ & $0.054^{* * *}$ & $0.055^{* * *}$ & $0.054^{* * *}$ & $0.055^{* * *}$ & $0.056^{* * *}$ & $0.056^{* * *}$ \\
\hline & $(0.011)$ & $(0.011)$ & $(0.011)$ & $(0.011)$ & $(0.011)$ & $(0.011)$ & $(0.011)$ & $(0.011)$ \\
\hline \multirow[t]{2}{*}{ PARTIME } & $0.144^{* * *}$ & $0.143^{* * *}$ & $0.143^{* * *}$ & $0.141^{* * *}$ & $0.143^{* * *}$ & $0.142^{* * *}$ & $0.139^{* * *}$ & $0.135^{* * *}$ \\
\hline & $(0.025)$ & $(0.025)$ & $(0.025)$ & $(0.025)$ & $(0.025)$ & $(0.025)$ & $(0.025)$ & $(0.026)$ \\
\hline \multirow[t]{2}{*}{ TEACHING } & $0.088^{* * *}$ & $0.090^{* * * *}$ & $0.088^{* * *}$ & $0.091^{* * *}$ & $0.088^{* * *}$ & $0.091^{* * * *}$ & $0.101^{* * * *}$ & $0.106^{* * * *}$ \\
\hline & $(0.011)$ & $(0.012)$ & $(0.011)$ & $(0.013)$ & $(0.011)$ & $(0.012)$ & $(0.011)$ & $(0.012)$ \\
\hline \multirow[t]{2}{*}{ PhDYRJOB } & 0.003 & 0.003 & 0.003 & 0.004 & 0.003 & 0.003 & 0.001 & 0.003 \\
\hline & $(0.014)$ & $(0.014)$ & $(0.014)$ & $(0.014)$ & $(0.014)$ & $(0.014)$ & $(0.014)$ & $(0.014)$ \\
\hline \multirow[t]{2}{*}{ WKEXPYR } & -0.000 & -0.000 & -0.000 & -0.000 & -0.000 & -0.000 & -0.000 & -0.001 \\
\hline & $(0.004)$ & $(0.004)$ & $(0.004)$ & $(0.004)$ & $(0.004)$ & $(0.004)$ & $(0.004)$ & $(0.004)$ \\
\hline \multirow[t]{2}{*}{ _cons } & $4.077^{* * *}$ & $4.024^{* * *}$ & $4.071^{* * *}$ & $4.031^{* * *}$ & $4.082^{* * *}$ & $4.074^{* * *}$ & $4.048^{* * *}$ & $3.966^{\text {**** }}$ \\
\hline & $(0.107)$ & $(0.109)$ & $(0.108)$ & $(0.114)$ & $(0.107)$ & $(0.108)$ & $(0.106)$ & $(0.115)$ \\
\hline$N$ & 5778 & 5778 & 5778 & 5778 & 5778 & 5778 & 5778 & 5778 \\
\hline$R^{2}$ & 0.257 & 0.257 & 0.257 & 0.256 & 0.257 & 0.256 & 0.249 & 0.242 \\
\hline adj. $R^{2}$ & 0.250 & 0.249 & 0.250 & 0.248 & 0.249 & 0.249 & 0.241 & 0.235 \\
\hline rmse & 0.373 & 0.371 & 0.373 & 0.371 & 0.373 & 0.371 & 0.375 & 0.375 \\
\hline VIF & 5.04 & 5 & 4.93 & 4.81 & 5.04 & 4.85 & 5.06 & 4.94 \\
\hline FSTAGE & & $716.912^{* * *}$ & & $113.243^{* * *}$ & & $506.931^{* * *}$ & & $382.458^{* * *}$ \\
\hline WEAK & & $723.33^{* * *}$ & & & & $570.253^{* * *}$ & & $322.869^{* * * *}$ \\
\hline ENDOG & & 0.179011 & & 0.774229 & & 0.26676 & & 3.01337 \\
\hline
\end{tabular}


Table 5. Earnings equations. Wage effect of genuine overeducation/ interaction with job satisfaction

\begin{tabular}{|c|c|c|c|c|c|c|c|c|}
\hline & \multicolumn{2}{|c|}{$\begin{array}{c}\text { (1) } \\
\text { OVEREDUCATION }\end{array}$} & \multicolumn{2}{|c|}{$\begin{array}{c}\text { (2) } \\
\text { OVEREDUCATION* } \\
\text { SATISFACTION }\end{array}$} & \multicolumn{2}{|c|}{$\begin{array}{c}\text { (3) } \\
\text { GENUINE } \\
\text { OVEREDUCATION }\end{array}$} & \multicolumn{2}{|c|}{$\begin{array}{c}(4) \\
\text { SATISFACTION }\end{array}$} \\
\hline & OLS & IV & OLS & IV & OLS & IV & OLS & IV \\
\hline OVEREDUCATION & $\begin{array}{l}-0.118^{* * *} \\
(0.016)\end{array}$ & $\begin{array}{l}-0.101^{*} \\
(0.044)\end{array}$ & & & & & & \\
\hline $\mathrm{AM}$ & & & $\begin{array}{l}-0.080^{* * *} \\
(0.022)\end{array}$ & $\begin{array}{l}-0.029 \\
(0.073)\end{array}$ & & & & \\
\hline $\mathrm{AO}$ & & & $\begin{array}{l}-0.104^{* * *} \\
(0.017)\end{array}$ & $\begin{array}{l}-0.067 \\
(0.046)\end{array}$ & & & & \\
\hline GO & & & $\begin{array}{l}-0.224^{* * *} \\
(0.035)\end{array}$ & $\begin{array}{l}-0.256^{* *} \\
(0.086)\end{array}$ & $\begin{array}{l}-0.182^{* * *} \\
(0.034)\end{array}$ & $\begin{array}{l}-0.238^{* *} \\
(0.084)\end{array}$ & & \\
\hline SATISFACTION & & & & & & & $\begin{array}{l}0.105^{* * *} \\
(0.019)\end{array}$ & $\begin{array}{l}0.071 \\
(0.073)\end{array}$ \\
\hline 2006 & $\begin{array}{l}-0.041^{* * *} \\
(0.011)\end{array}$ & $\begin{array}{l}-0.042^{* * *} \\
(0.011)\end{array}$ & $\begin{array}{l}-0.042^{* * *} \\
(0.011)\end{array}$ & $\begin{array}{l}-0.043^{* * *} \\
(0.011)\end{array}$ & $\begin{array}{l}-0.044^{* * *} \\
(0.011)\end{array}$ & $\begin{array}{l}-0.044^{* * *} \\
(0.011)\end{array}$ & $\begin{array}{l}-0.045^{* * *} \\
(0.011)\end{array}$ & $\begin{array}{l}-0.045^{* * *} \\
(0.011)\end{array}$ \\
\hline NORTHWEST & $\begin{array}{l}-0.379^{* * *} \\
(0.023)\end{array}$ & $\begin{array}{l}-0.380^{* * *} \\
(0.023)\end{array}$ & $\begin{array}{l}-0.375^{* * *} \\
(0.023)\end{array}$ & $\begin{array}{l}-0.379^{* * *} \\
(0.024)\end{array}$ & $\begin{array}{l}-0.384^{* * *} \\
(0.023)\end{array}$ & $\begin{array}{l}-0.383^{* * *} \\
(0.023)\end{array}$ & $\begin{array}{l}-0.379^{* * *} \\
(0.023)\end{array}$ & $\begin{array}{l}-0.381^{* * *} \\
(0.024)\end{array}$ \\
\hline NORTEAST & $\begin{array}{l}-0.400^{* * *} \\
(0.023)\end{array}$ & $\begin{array}{l}-0.401^{* * *} \\
(0.023)\end{array}$ & $\begin{array}{l}-0.398^{* * *} \\
(0.023)\end{array}$ & $\begin{array}{l}-0.401^{\text {*** }} \\
(0.024)\end{array}$ & $\begin{array}{l}-0.406^{* * *} \\
(0.023)\end{array}$ & $\begin{array}{l}-0.406^{* * *} \\
(0.023)\end{array}$ & $\begin{array}{l}-0.403^{* * *} \\
(0.024)\end{array}$ & $\begin{array}{l}-0.404^{* * *} \\
(0.024)\end{array}$ \\
\hline CENTRE & $\begin{array}{l}-0.384^{* * *} \\
(0.024)\end{array}$ & $\begin{array}{l}-0.385^{* * *} \\
(0.024)\end{array}$ & $\begin{array}{l}-0.379^{* * *} \\
(0.024)\end{array}$ & $\begin{array}{l}-0.383^{* * *} \\
(0.024)\end{array}$ & $\begin{array}{l}-0.388^{* * *} \\
(0.024)\end{array}$ & $\begin{array}{l}-0.388^{* * *} \\
(0.024)\end{array}$ & $\begin{array}{l}-0.384^{* * *} \\
(0.024)\end{array}$ & $\begin{array}{l}-0.386^{* * *} \\
(0.024)\end{array}$ \\
\hline SOUTH & $\begin{array}{l}-0.409^{* * *} \\
(0.024)\end{array}$ & $\begin{array}{l}-0.411^{* * *} \\
(0.024)\end{array}$ & $\begin{array}{l}-0.404^{* * *} \\
(0.024)\end{array}$ & $\begin{array}{l}-0.408^{* * *} \\
(0.025)\end{array}$ & $\begin{array}{l}-0.414^{* * *} \\
(0.024)\end{array}$ & $\begin{array}{l}-0.413^{* * *} \\
(0.024)\end{array}$ & $\begin{array}{l}-0.409^{* * *} \\
(0.024)\end{array}$ & $\begin{array}{l}-0.412^{* * *} \\
(0.025)\end{array}$ \\
\hline $\begin{array}{ll}\text { PHYSICS } & \& \\
\text { ASTRONOMY } & \end{array}$ & $0.073^{* *}$ & 0.046 & $0.072^{*}$ & 0.044 & $0.070^{*}$ & 0.047 & $0.071^{*}$ & 0.049 \\
\hline & $(0.028)$ & $(0.037)$ & $(0.028)$ & $(0.036)$ & $(0.028)$ & $(0.036)$ & $(0.028)$ & $(0.037)$ \\
\hline $\begin{array}{l}\text { EARTH \& } \\
\text { ENVIROMENTAL } \\
\text { SCIENCE }\end{array}$ & -0.015 & $0.119^{* * *}$ & -0.013 & $0.115^{* * *}$ & -0.014 & $0.117^{\text {**** }}$ & -0.013 & $0.120^{* * *}$ \\
\hline & $(0.026)$ & $(0.034)$ & $(0.026)$ & $(0.034)$ & $(0.026)$ & $(0.034)$ & $(0.026)$ & $(0.034)$ \\
\hline CHIMESTRY & $\begin{array}{l}0.024 \\
(0.034)\end{array}$ & $\begin{array}{l}0.031 \\
(0.033)\end{array}$ & $\begin{array}{l}0.024 \\
(0.034)\end{array}$ & $\begin{array}{l}0.031 \\
(0.032)\end{array}$ & $\begin{array}{l}0.021 \\
(0.035)\end{array}$ & $\begin{array}{l}0.033 \\
(0.032)\end{array}$ & $\begin{array}{l}0.021 \\
(0.034)\end{array}$ & $\begin{array}{l}0.035 \\
(0.033)\end{array}$ \\
\hline $\begin{array}{l}\text { BIOLOGICAL } \\
\text { SCIENCE }\end{array}$ & $-0.053^{*}$ & 0.070 & $-0.053^{*}$ & 0.068 & $-0.056^{*}$ & 0.067 & $-0.057^{*}$ & 0.069 \\
\hline & $(0.027)$ & $\begin{array}{l}(0.039) \\
-0008\end{array}$ & $\begin{array}{l}(0.027) \\
0.062^{*}\end{array}$ & $(0.039)$ & $\begin{array}{l}(0.027) \\
0.057\end{array}$ & $(0.039)$ & $(0.027)$ & $(0.039)$ \\
\hline & $(0.031)$ & $(0.032)$ & $(0.031)$ & $(0.032)$ & $(0.031)$ & $(0.032)$ & $(0.030)$ & $(0.032)$ \\
\hline
\end{tabular}




\begin{tabular}{|c|c|c|c|c|c|c|c|c|}
\hline \multirow{2}{*}{$\begin{array}{l}\text { AGRICULTURE\&V } \\
\text { ETERINARY }\end{array}$} & -0.011 & $0.112^{* *}$ & -0.007 & $0.104^{* *}$ & -0.010 & $0.103^{* *}$ & -0.007 & $0.106^{* *}$ \\
\hline & $(0.030)$ & $(0.035)$ & $(0.030)$ & $(0.035)$ & $(0.030)$ & $(0.035)$ & $(0.030)$ & $(0.035)$ \\
\hline \multirow[t]{2}{*}{ ARCHITECTURE } & -0.033 & 0.036 & -0.032 & 0.036 & -0.034 & 0.037 & -0.034 & 0.040 \\
\hline & $(0.031)$ & $(0.034)$ & $(0.031)$ & $(0.034)$ & $(0.031)$ & $(0.034)$ & $(0.031)$ & $(0.034)$ \\
\hline \multirow{2}{*}{$\begin{array}{l}\text { ENGINEERING } \\
\text { SCIENCE }\end{array}$} & 0.054 & 0.013 & 0.053 & 0.012 & 0.051 & 0.013 & 0.055 & 0.015 \\
\hline & $(0.029)$ & $(0.035)$ & $(0.029)$ & $(0.035)$ & $(0.029)$ & $(0.035)$ & $(0.029)$ & $(0.035)$ \\
\hline \multirow[t]{2}{*}{ HUMAN SCIENCE } & -0.003 & $0.100^{* *}$ & -0.001 & $0.096^{* *}$ & -0.004 & $0.097^{* *}$ & -0.005 & $0.104^{* *}$ \\
\hline & $(0.031)$ & $(0.034)$ & $(0.031)$ & $(0.034)$ & $(0.031)$ & $(0.034)$ & $(0.031)$ & $(0.034)$ \\
\hline \multirow{2}{*}{$\begin{array}{l}\text { HISTORY } \\
\text { PHILOSOPHY }\end{array}$} & -0.042 & 0.043 & -0.041 & 0.043 & -0.044 & 0.044 & -0.044 & 0.043 \\
\hline & $(0.029)$ & $(0.035)$ & $(0.029)$ & $(0.035)$ & $(0.030)$ & $(0.035)$ & $(0.029)$ & $(0.035)$ \\
\hline \multirow[t]{2}{*}{ LAW } & 0.025 & 0.004 & 0.024 & 0.002 & 0.021 & 0.003 & 0.020 & 0.004 \\
\hline & $(0.033)$ & $(0.034)$ & $(0.032)$ & $(0.034)$ & $(0.033)$ & $(0.034)$ & $(0.032)$ & $(0.034)$ \\
\hline \multirow{2}{*}{$\begin{array}{l}\text { ECONOMICS } \\
\text { STATISTICS }\end{array}$} & 0.025 & 0.071 & 0.025 & 0.068 & 0.025 & 0.069 & 0.026 & 0.069 \\
\hline & $(0.030)$ & $(0.037)$ & $(0.030)$ & $(0.036)$ & $(0.030)$ & $(0.036)$ & $(0.030)$ & $(0.037)$ \\
\hline \multirow{2}{*}{$\begin{array}{l}\text { POLITICAL } \\
\text { SCIENCE }\end{array}$} & -0.046 & $0.072^{*}$ & -0.044 & $0.069^{*}$ & -0.048 & $0.071^{*}$ & -0.048 & $0.075^{*}$ \\
\hline & $(0.037)$ & $(0.035)$ & $(0.037)$ & $(0.035)$ & $(0.037)$ & $(0.035)$ & $(0.037)$ & $(0.035)$ \\
\hline \multirow[t]{2}{*}{ WORKSHOP } & -0.014 & -0.014 & -0.013 & -0.012 & -0.012 & -0.011 & -0.015 & -0.015 \\
\hline & $(0.021)$ & $(0.021)$ & $(0.021)$ & $(0.021)$ & $(0.021)$ & $(0.021)$ & $(0.021)$ & $(0.021)$ \\
\hline \multirow{2}{*}{ COURSES } & 0.003 & 0.004 & 0.003 & 0.004 & 0.005 & 0.005 & 0.005 & 0.005 \\
\hline & $(0.014)$ & $(0.014)$ & $(0.014)$ & $(0.014)$ & $(0.014)$ & $(0.014)$ & $(0.014)$ & $(0.014)$ \\
\hline \multirow[t]{2}{*}{ SUMMERSCHOOL } & 0.008 & 0.008 & 0.009 & 0.009 & 0.010 & 0.010 & 0.010 & 0.010 \\
\hline & $(0.012)$ & $(0.012)$ & $(0.012)$ & $(0.012)$ & $(0.012)$ & $(0.012)$ & $(0.012)$ & $(0.012)$ \\
\hline \multirow[t]{2}{*}{ OTHERFINIMP } & 0.038 & 0.037 & 0.037 & 0.036 & 0.034 & 0.034 & 0.034 & 0.034 \\
\hline & $(0.020)$ & $(0.020)$ & $(0.020)$ & $(0.020)$ & $(0.020)$ & $(0.020)$ & $(0.020)$ & $(0.020)$ \\
\hline \multirow[t]{2}{*}{ TAUGHT } & -0.000 & -0.000 & -0.001 & -0.001 & -0.001 & -0.001 & -0.002 & -0.002 \\
\hline & $(0.011)$ & $(0.011)$ & $(0.011)$ & $(0.011)$ & $(0.011)$ & $(0.011)$ & $(0.011)$ & $(0.011)$ \\
\hline \multirow[t]{2}{*}{ FROMDTOPHD } & $0.033^{* * *}$ & $0.033^{* * *}$ & $0.033^{* * *}$ & $0.034^{* * *}$ & $0.034^{* * *}$ & $0.034^{* * *}$ & $0.033^{* * *}$ & $0.033^{* * *}$ \\
\hline & $(0.006)$ & $(0.006)$ & $(0.006)$ & $(0.006)$ & $(0.006)$ & $(0.006)$ & $(0.006)$ & $(0.006)$ \\
\hline \multirow[t]{2}{*}{ FROMDTOPHD2 } & -0.001 & -0.001 & -0.001 & -0.001 & -0.001 & -0.001 & -0.001 & -0.001 \\
\hline & $(0.000)$ & $(0.000)$ & $(0.000)$ & $(0.000)$ & $(0.000)$ & $(0.000)$ & $(0.000)$ & $(0.000)$ \\
\hline \multirow[t]{2}{*}{ DEGREE 91-100 } & 0.079 & 0.079 & 0.081 & 0.079 & 0.079 & 0.078 & 0.080 & 0.080 \\
\hline & $(0.096)$ & $(0.095)$ & $(0.097)$ & $(0.097)$ & $(0.097)$ & $(0.098)$ & $(0.095)$ & $(0.094)$ \\
\hline \multirow[t]{2}{*}{ DEGREE 101-05 } & 0.101 & 0.102 & 0.104 & 0.104 & 0.104 & 0.105 & 0.106 & 0.105 \\
\hline & $(0.095)$ & $(0.094)$ & $(0.095)$ & $(0.096)$ & $(0.096)$ & $(0.096)$ & $(0.093)$ & $(0.092)$ \\
\hline \multirow[t]{2}{*}{ DEGREE 106-09 } & 0.122 & 0.122 & 0.122 & 0.121 & 0.121 & 0.120 & 0.121 & 0.121 \\
\hline & $(0.094)$ & (0.094) & $(0.095)$ & $(0.096)$ & $(0.096)$ & $(0.096)$ & $(0.093)$ & $(0.092)$ \\
\hline DEGREE 110 & 0.123 & 0.123 & 0.124 & 0.122 & 0.122 & 0.122 & 0.126 & 0.125 \\
\hline
\end{tabular}




\begin{tabular}{|c|c|c|c|c|c|c|c|c|}
\hline & $(0.094)$ & $(0.093)$ & $(0.094)$ & $(0.095)$ & $(0.095)$ & $(0.096)$ & $(0.092)$ & $(0.092)$ \\
\hline \multirow{2}{*}{ GRANT } & 0.006 & 0.005 & 0.005 & 0.003 & 0.002 & 0.001 & 0.003 & 0.003 \\
\hline & $(0.015)$ & $(0.015)$ & $(0.015)$ & $(0.015)$ & $(0.015)$ & $(0.015)$ & $(0.015)$ & $(0.015)$ \\
\hline \multirow[t]{2}{*}{ EXTENSION } & 0.010 & 0.010 & 0.011 & 0.011 & 0.012 & 0.012 & 0.011 & 0.011 \\
\hline & $(0.019)$ & $(0.019)$ & $(0.019)$ & $(0.019)$ & $(0.019)$ & $(0.019)$ & $(0.019)$ & $(0.019)$ \\
\hline \multirow{2}{*}{ GRADUATE } & 0.013 & 0.013 & 0.012 & 0.012 & 0.010 & 0.010 & 0.009 & 0.010 \\
\hline & $(0.013)$ & $(0.013)$ & $(0.013)$ & $(0.013)$ & $(0.013)$ & $(0.013)$ & $(0.013)$ & $(0.013)$ \\
\hline \multirow[t]{2}{*}{ Msc, MPhil OR PhD } & -0.005 & -0.005 & -0.005 & -0.006 & -0.007 & -0.007 & -0.007 & -0.007 \\
\hline & $(0.013)$ & $(0.013)$ & $(0.013)$ & $(0.013)$ & $(0.013)$ & $(0.013)$ & $(0.013)$ & $(0.013)$ \\
\hline \multirow[t]{2}{*}{30 YEARS } & 0.004 & 0.004 & 0.005 & 0.005 & 0.005 & 0.005 & 0.005 & 0.004 \\
\hline & $(0.015)$ & $(0.015)$ & $(0.015)$ & $(0.015)$ & $(0.015)$ & $(0.015)$ & $(0.015)$ & $(0.015)$ \\
\hline \multirow[t]{2}{*}{31 YEARS } & -0.023 & -0.023 & -0.021 & -0.022 & -0.023 & -0.022 & -0.023 & -0.024 \\
\hline & $(0.016)$ & $(0.016)$ & $(0.016)$ & $(0.016)$ & $(0.016)$ & $(0.016)$ & $(0.016)$ & $(0.016)$ \\
\hline \multirow[t]{2}{*}{32 YEARS } & -0.034 & -0.034 & -0.032 & -0.034 & $-0.036^{*}$ & $-0.036^{*}$ & -0.035 & $-0.035^{*}$ \\
\hline & $(0.018)$ & $(0.018)$ & $(0.018)$ & $(0.018)$ & $(0.018)$ & $(0.018)$ & $(0.018)$ & $(0.018)$ \\
\hline \multirow[t]{2}{*}{33 AND MORE } & $-0.040^{*}$ & $-0.040^{*}$ & -0.036 & $-0.037^{*}$ & $-0.038^{*}$ & $-0.038^{*}$ & -0.035 & -0.036 \\
\hline & $(0.019)$ & $(0.019)$ & $(0.019)$ & $(0.019)$ & $(0.019)$ & $(0.019)$ & $(0.019)$ & $(0.019)$ \\
\hline \multirow[t]{2}{*}{ FEMALE } & $-0.040^{*}$ & $-0.041^{*}$ & $-0.040^{*}$ & $-0.040^{*}$ & $-0.039^{*}$ & $-0.040^{*}$ & $-0.039^{*}$ & $-0.039^{*}$ \\
\hline & $(0.017)$ & $(0.016)$ & $(0.016)$ & $(0.016)$ & $(0.016)$ & $(0.016)$ & $(0.016)$ & $(0.016)$ \\
\hline \multirow[t]{2}{*}{ MARRIED } & -0.014 & -0.014 & -0.015 & -0.015 & -0.015 & -0.015 & -0.015 & -0.015 \\
\hline & $(0.017)$ & $(0.017)$ & $(0.017)$ & $(0.017)$ & $(0.017)$ & $(0.017)$ & $(0.017)$ & $(0.017)$ \\
\hline \multirow{2}{*}{$\begin{array}{l}\text { FEMALE } \\
\text { MARRIED }\end{array}$} & $-0.051^{* *}$ & 0.004 & $-0.053^{* *}$ & 0.002 & $-0.053^{* *}$ & 0.000 & $-0.053^{* *}$ & 0.002 \\
\hline & $(0.016)$ & $(0.020)$ & $(0.016)$ & $(0.020)$ & $(0.016)$ & $(0.020)$ & $(0.016)$ & $(0.020)$ \\
\hline \multirow[t]{2}{*}{ CHILDREN } & $0.072^{* * *}$ & $0.072^{* * *}$ & $0.071^{* * *}$ & $0.071^{* * *}$ & $0.072^{* * *}$ & $0.071^{* * *}$ & $0.071^{* * *}$ & $0.072^{* * *}$ \\
\hline & $(0.013)$ & $(0.013)$ & $(0.013)$ & $(0.013)$ & $(0.013)$ & $(0.013)$ & $(0.013)$ & $(0.013)$ \\
\hline \multirow[t]{2}{*}{ PARENTLIVE } & $-0.046^{* *}$ & $-0.047^{* *}$ & $-0.045^{* *}$ & $-0.045^{* *}$ & $-0.046^{* *}$ & $-0.046^{* *}$ & $-0.046^{* *}$ & $-0.046^{* *}$ \\
\hline & $(0.017)$ & $(0.017)$ & $(0.017)$ & $(0.017)$ & $(0.017)$ & $(0.017)$ & $(0.017)$ & $(0.017)$ \\
\hline \multirow[t]{2}{*}{ PRODUCTS } & -0.002 & -0.002 & -0.002 & -0.002 & -0.002 & -0.001 & -0.002 & -0.002 \\
\hline & $(0.003)$ & $(0.003)$ & $(0.003)$ & $(0.003)$ & $(0.003)$ & $(0.003)$ & $(0.003)$ & $(0.003)$ \\
\hline \multirow[t]{2}{*}{ SELFEMPLOYED } & $-0.175^{* * *}$ & $-0.179^{* * *}$ & $-0.185^{* * *}$ & $-0.187^{* * *}$ & $-0.197^{* * *}$ & $-0.197^{* * *}$ & $-0.208^{* * *}$ & $-0.205^{* * *}$ \\
\hline & $(0.027)$ & $(0.029)$ & $(0.027)$ & $(0.030)$ & $(0.027)$ & $(0.027)$ & $(0.027)$ & $(0.028)$ \\
\hline \multirow[t]{2}{*}{ PERMANENT } & 0.013 & 0.012 & 0.007 & 0.008 & 0.005 & 0.005 & -0.001 & 0.001 \\
\hline & $(0.011)$ & $(0.011)$ & $(0.011)$ & $(0.012)$ & $(0.011)$ & $(0.011)$ & $(0.011)$ & $(0.011)$ \\
\hline \multirow[t]{2}{*}{ ACADEMY } & $-0.258^{* * *}$ & $-0.257^{* * *}$ & $-0.257^{* * *}$ & $-0.257^{* * *}$ & $-0.252^{* * *}$ & $-0.252^{* * *}$ & $-0.248^{* * *}$ & $-0.248^{* * *}$ \\
\hline & $(0.016)$ & $(0.016)$ & $(0.016)$ & $(0.016)$ & $(0.016)$ & $(0.016)$ & $(0.016)$ & $(0.016)$ \\
\hline \multirow[t]{2}{*}{ ONLY RD } & $-0.130^{* * *}$ & $-0.126^{* * *}$ & $-0.137^{* * *}$ & $-0.130^{* * * *}$ & $-0.111^{* * *}$ & $-0.115^{* * *}$ & $-0.112^{* * *}$ & $-0.108^{* * *}$ \\
\hline & $(0.019)$ & $(0.021)$ & $(0.019)$ & $(0.022)$ & $(0.018)$ & $(0.019)$ & $(0.018)$ & $(0.019)$ \\
\hline \multirow[t]{2}{*}{ PARTIALLY RD } & $-0.043^{*}$ & $-0.040^{*}$ & $-0.049^{* *}$ & $-0.045^{*}$ & $-0.034^{*}$ & $-0.037^{*}$ & $-0.034^{*}$ & -0.031 \\
\hline & $(0.017)$ & $(0.018)$ & $(0.017)$ & $(0.018)$ & $(0.017)$ & $(0.017)$ & $(0.017)$ & $(0.017)$ \\
\hline \multirow[t]{2}{*}{ AGRICULTURE } & $-0.211^{* * *}$ & $-0.213^{* * *}$ & $-0.216^{* * *}$ & $-0.218^{* * *}$ & $-0.224^{* * * *}$ & $-0.224^{* * *}$ & $-0.228^{* * *}$ & $-0.226^{* * *}$ \\
\hline & $(0.034)$ & $(0.034)$ & $(0.034)$ & $(0.034)$ & $(0.034)$ & $(0.034)$ & $(0.034)$ & $(0.034)$ \\
\hline
\end{tabular}




\begin{tabular}{|c|c|c|c|c|c|c|c|c|}
\hline MANUFACTURE & $\begin{array}{l}-0.074^{* * *} \\
(0.019)\end{array}$ & $\begin{array}{l}-0.075^{* * *} \\
(0.019)\end{array}$ & $\begin{array}{l}-0.072^{* * *} \\
(0.019)\end{array}$ & $\begin{array}{l}-0.072^{* * *} \\
(0.019)\end{array}$ & $\begin{array}{l}-0.076^{* * *} \\
(0.019)\end{array}$ & $\begin{array}{l}-0.074^{* * *} \\
(0.019)\end{array}$ & $\begin{array}{l}-0.077^{* * *} \\
(0.019)\end{array}$ & $\begin{array}{l}-0.078^{* * *} \\
(0.019)\end{array}$ \\
\hline \multirow[t]{2}{*}{ MIGRANT } & $0.054^{* * *}$ & $0.055^{* * *}$ & $0.054^{* * *}$ & $0.055^{* * *}$ & $0.056^{* * *}$ & $0.056^{* * *}$ & $0.055^{* * *}$ & $0.055^{* * *}$ \\
\hline & $(0.011)$ & $(0.011)$ & $(0.011)$ & $(0.011)$ & $(0.011)$ & $(0.011)$ & $(0.011)$ & $(0.011)$ \\
\hline \multirow[t]{2}{*}{ PARTIME } & $0.144^{* * *}$ & $0.143^{* * *}$ & $0.153^{* * *}$ & $0.152^{* * *}$ & $0.147^{* * *}$ & $0.149^{* * *}$ & $0.151^{* * *}$ & $0.147^{* * *}$ \\
\hline & $(0.025)$ & $(0.025)$ & $(0.025)$ & $(0.026)$ & $(0.025)$ & $(0.026)$ & $(0.025)$ & $(0.026)$ \\
\hline \multirow[t]{2}{*}{ TEACHING } & $0.088^{* * *}$ & $0.090^{* * *}$ & $0.087^{* * *}$ & $0.089^{* * *}$ & $0.097^{* * *}$ & $0.096^{* * *}$ & $0.099^{* * *}$ & $0.100^{* * *}$ \\
\hline & $(0.011)$ & $(0.012)$ & $(0.011)$ & $(0.012)$ & $(0.011)$ & $(0.011)$ & $(0.011)$ & $(0.011)$ \\
\hline \multirow[t]{2}{*}{ PhDYRJOB } & 0.003 & 0.003 & 0.002 & 0.001 & 0.001 & 0.001 & -0.000 & 0.000 \\
\hline & $(0.014)$ & $(0.014)$ & $(0.014)$ & $(0.014)$ & $(0.014)$ & $(0.014)$ & $(0.014)$ & $(0.014)$ \\
\hline \multirow[t]{2}{*}{ WKEXPYR } & -0.000 & -0.000 & -0.000 & -0.000 & -0.000 & -0.000 & -0.000 & -0.000 \\
\hline & $(0.004)$ & $(0.004)$ & $(0.004)$ & $(0.004)$ & $(0.004)$ & $(0.004)$ & $(0.004)$ & $(0.004)$ \\
\hline \multirow[t]{2}{*}{ _cons } & $4.077^{* * *}$ & $4.024^{* * *}$ & $4.089^{* * *}$ & $4.034^{* * *}$ & $4.054^{* * *}$ & $4.012^{* * *}$ & $3.954^{* * *}$ & $3.934^{* * *}$ \\
\hline & $(0.107)$ & $(0.109)$ & $(0.107)$ & $(0.112)$ & $(0.108)$ & $(0.111)$ & $(0.107)$ & $(0.119)$ \\
\hline$N$ & 5778 & 5778 & 5778 & 5778 & 5778 & 5778 & 5776 & 5776 \\
\hline$R^{2}$ & 0.257 & 0.257 & 0.261 & 0.259 & 0.254 & 0.254 & 0.254 & 0.253 \\
\hline adj. $R^{2}$ & 0.250 & 0.249 & 0.254 & 0.252 & 0.247 & 0.246 & 0.247 & 0.246 \\
\hline rmse & 0.373 & 0.371 & 0.372 & 0.371 & 0.374 & 0.372 & 0.374 & 0.372 \\
\hline VIF & 5.04 & 5 & 4.9 & 4.87 & 5.03 & 4.97 & 5.03 & 5.20 \\
\hline FSTAGE & & $716.912^{* * *}$ & & $208.357^{* * *}$ & & $139.539^{* * *}$ & & $293.549^{* * *}$ \\
\hline WEAK IV & & $723.33^{* * *}$ & & & & $717.121^{* * *}$ & & $386.054^{* * *}$ \\
\hline ENDOG & & 0.179011 & & 1.55964 & & 0.517847 & & 0.237478 \\
\hline
\end{tabular}

${ }^{*} p<0.05$, ** $p<0.01$, *** $\left.p<0.001\right)$ 
Fig. 1: Yearly number of new doctoral graduates

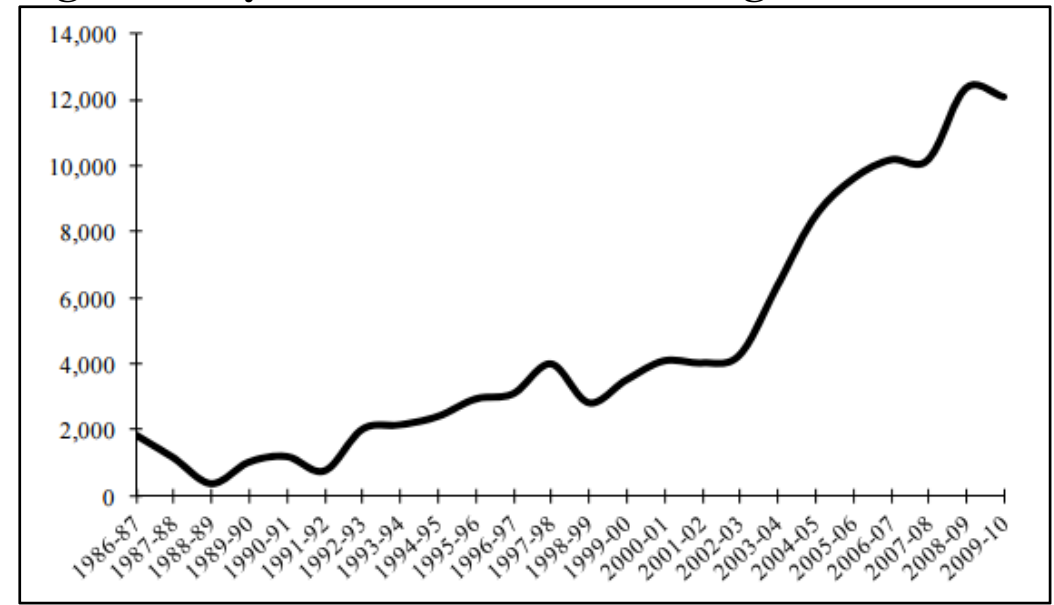

Source: Argentin et al. (2014).

Fig. 2: Personnel employed in R\&D activities per 1000 inhabitants. European countries' and $E U(28)$ data.

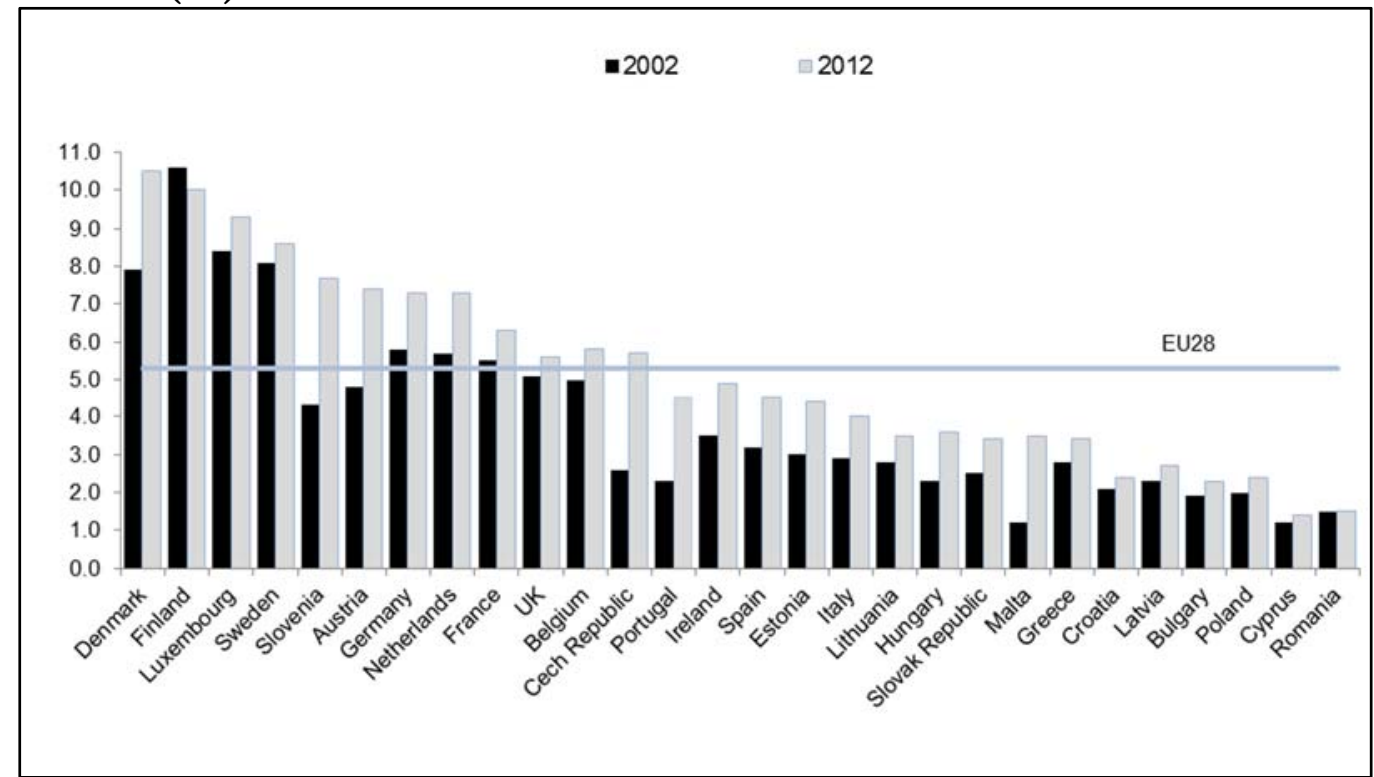

Source: Italian National Institute of Statistics (ISTAT). 
Fig. 3: Number of Assistant Professors and total personnel in Italian Universities, 20022012.

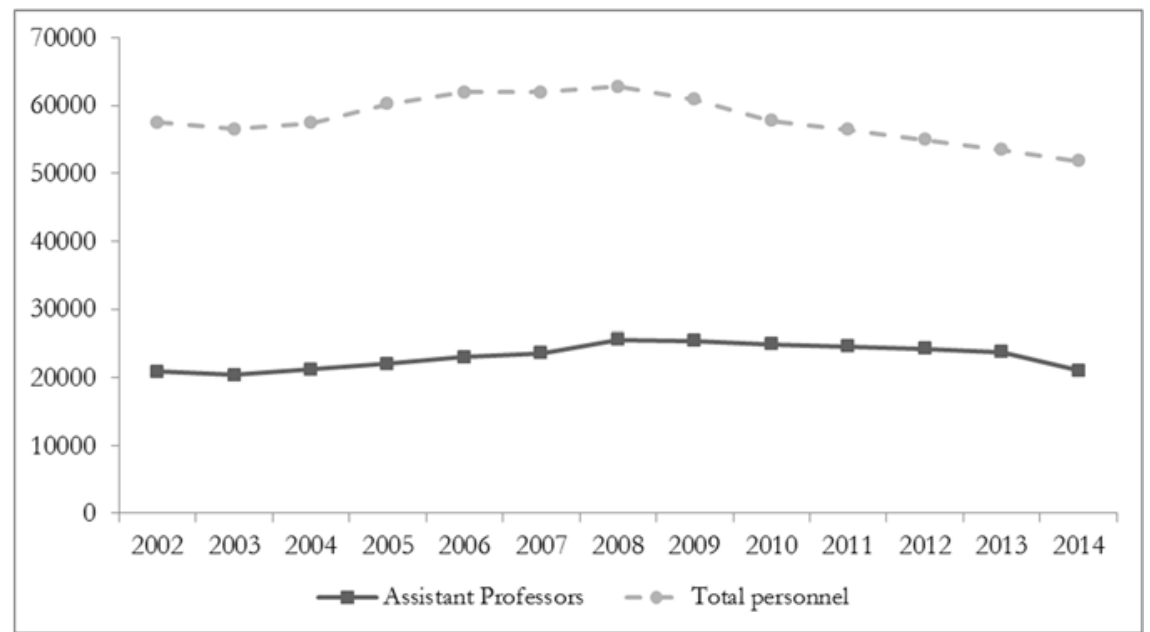

Note: The total personnel is the sum of Assistant Professors, Associate Professors and Full Professors. Source: MIUR Italian Ministry of Education, Universities and Research.

Fig. 4: Personnel employed in R\&D by the Italian Public Administration and by private enterprises per 1000 inhabitants.

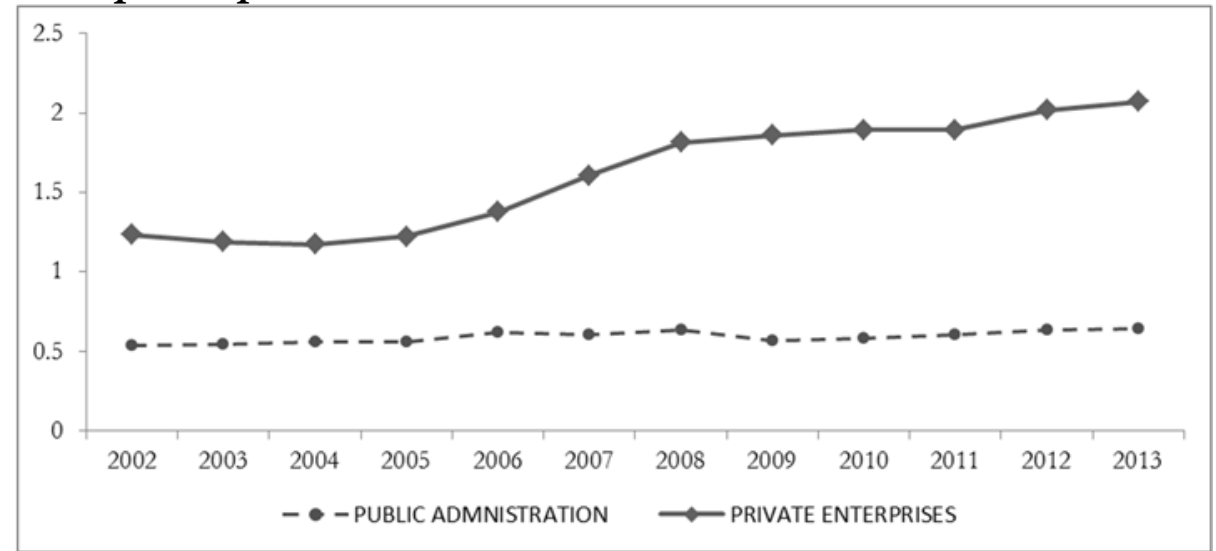

Source: Italian National Institute of Statistics (ISTAT). 


\section{$\underline{\text { Annex }}$}

Table A1: Variables' definition. \ indicates reference categories in regression analyses. VARIABLE VARIABLE LABEL VARIABLE DESCRIPTION

GROUP

\begin{tabular}{|c|c|c|}
\hline DEP. VARIABLE & LNWAGE & $\begin{array}{l}\text { Natural logarithm of hourly net income: } \ln (\text { Monthly } \\
\text { net wage/Hours) }\end{array}$ \\
\hline \multirow{9}{*}{$\begin{array}{l}\text { MAIN } \\
\text { REGRESSORS }\end{array}$} & OVEREDUCATION & $1=\mathrm{PhD}$ was not required nor useful to obtain the current job \\
\hline & SATISFACTION & $1=$ Are you satisfied of your job 0 otherwise \\
\hline & AM & Apparent matching Over-education $=0 \&$ Satisfaction $=0$ \\
\hline & $\mathrm{AO}$ & Apparent over-education Over-education $=1 \&$ Satisfaction $=1$ \\
\hline & GM & Genuine matching Over-education $=1 \&$ Satisfaction $=0$ \\
\hline & OVERSKILLING & $1=$ Are you satisfied of your job 0 otherwise \\
\hline & $\mathrm{AM}$ & Apparent matching Over-education $=0 \&$ Over-skilling $=0$ \\
\hline & $\mathrm{AO}$ & Apparent over-education Over-education $=1$ \& Over-skilling $=1$ \\
\hline & GM & Genuine matching Over-education $=1 \&$ Over-skilling $=0$ \\
\hline \multirow[t]{6}{*}{ IV } & OVEREDUCATION & $\begin{array}{l}\text { over-education rate among those who completed their Ph.D. in the same } \\
\text { year of respondent, studied the same discipline in the same province }\end{array}$ \\
\hline & SATISFACTION & $\begin{array}{l}\text { Satisfaction rate among those who completed their Ph.D. in the same } \\
\text { year of respondent, studied the same discipline in the same province }\end{array}$ \\
\hline & $\mathrm{AM}$ & $\begin{array}{l}\text { Apparent matching rate among those who completed their Ph.D. in the } \\
\text { same year of respondent, studied the same discipline in the same province }\end{array}$ \\
\hline & $\mathrm{AO}$ & $\begin{array}{l}\text { Apparent Over-education rate among those who completed their Ph.D. } \\
\text { in the same year of respondent, studied the same discipline in the same } \\
\text { province }\end{array}$ \\
\hline & GM & $\begin{array}{l}\text { Genuine Overeducated rate among those who completed their Ph.D. in } \\
\text { the same year of respondent, studied the same discipline in the same } \\
\text { province }\end{array}$ \\
\hline & OVERSKILLING & $\begin{array}{l}\text { Over-skilling rate among those who completed their Ph.D. in the same } \\
\text { year of respondent, studied the same discipline in the same province }\end{array}$ \\
\hline \multirow[t]{13}{*}{$\begin{array}{l}\text { SOCIO- } \\
\text { DEMOGRAPHIC }\end{array}$} & $\begin{array}{l}\text { AGECOMPLETE: } \quad \text { LESS } \\
\text { THAN } 30 \text { S }\end{array}$ & $1=$ Ph.D. achieved at less than 30 \\
\hline & AGECOMPLETE: & $1=$ Ph.D. achieved at 30 \\
\hline & YEARS & \\
\hline & $\begin{array}{l}\text { AGECOMPLETE: } \\
\text { YEARS }\end{array}$ & $1=\mathrm{Ph} . \mathrm{D}$. achieved at 31 \\
\hline & $\begin{array}{l}\text { AGECOMPLETE: } \\
\text { YEARS }\end{array}$ & $1=$ Ph.D. achieved at: 32 \\
\hline & $\begin{array}{l}\text { AGECOMPLETE: } 33 \text { AND } \\
\text { MORE }\end{array}$ & $1=$ Ph.D. achieved at 33 or more \\
\hline & FEMALE & $1=$ Female \\
\hline & MARRIED & $1=$ Married \\
\hline & CHILDREN & $1=$ has at least one child \\
\hline & $\begin{array}{l}\text { HIGHERFAMGRADE }= \\
\text { undergraduate }\end{array}$ & $1=$ higher parents' education is undergraduate \\
\hline & $\begin{array}{l}\text { HIGHERFAMGRADE }=\text { Gra } \\
\text { duate }\end{array}$ & $1=$ higher parents' education is graduate \\
\hline & $\begin{array}{l}\text { HIGHERFAMGRADE }=\text { Msc } \\
\text { Mphil, Phd }\end{array}$ & $1=$ higher parents' education is Msc Mphil or Phd \\
\hline & PARENTLIVE & $1=$ lives with parents \\
\hline \multirow[t]{11}{*}{ STUDY FIELD } & MATH and STATISTICSS & $1=$ Math or Statistics was the Ph.D. field of study \\
\hline & PHYSICS & $1=$ Physics and Astronomy \\
\hline & ASTRONOMY & \\
\hline & EARTH and ENVIR. SC. & $1=$ Earth and environmental sciences \\
\hline & CHEMISTRY & $1=$ Chemisty \\
\hline & BIOLOGICAL SCIENCE & $1=$ Biological Science \\
\hline & MEDICAL SCIENCE & $1=$ Medical Science \\
\hline & AGRIC. and VETERINARY & $1=$ Agricolture and Veterinary \\
\hline & ARCHITECTURE & $1=$ Architecture \\
\hline & ENGINEERING SCIENCE & $1=$ Engineering \\
\hline & HUMAN SCIENCE & 1=Human Sciences \\
\hline
\end{tabular}




\begin{tabular}{|c|c|c|}
\hline & $\begin{array}{ll}\text { HISTORY } & \text { and } \\
\text { PHILOSOPHY } & \\
\text { LAW } & \\
\text { ECONOMICS } & \text { and } \\
\text { STATISTICS } & \\
\text { POLITICAL SCIENCE } & \end{array}$ & $\begin{array}{l}1=\text { History and Philosophy } \\
1=\text { Law } \\
1=\text { Economics and Statistics } \\
1=\text { Political Science }\end{array}$ \\
\hline PhD FEATURES & $\begin{array}{l}\text { WORKSHOP } \\
\text { COURSES } \\
\text { SUMMERSCHOOL } \\
\text { OTHERFINIMP } \\
\text { TAUGHT } \\
\text { GRANT } \\
\text { EXTENSION } \\
\text { YEAR=2004S } \\
\text { YEAR=2006 }\end{array}$ & $\begin{array}{l}1=\text { took part to workshop during Ph.D. } \\
1=\text { Took part to courses during Ph.D. } \\
1=\text { Took part to summer school during Ph.D. } \\
1=\text { Financial aid other than grant was used in order to } \\
\text { complete the Ph.D. } \\
1=\text { taught courses during Ph.D. } \\
1=\text { Grant received during Ph.D. } \\
1=\text { time extension needed to conclude Ph.D. } \\
1=\text { Ph.D. earned in } 2004 \\
1=\text { Ph.D. earned n } 2006\end{array}$ \\
\hline $\begin{array}{l}\text { PERFORMANCES } \\
\text { BEFORE PHD }\end{array}$ & $\begin{array}{l}\text { FROMDTOPHD } \\
\text { DEGREE } 66-90 \\
\text { DEGREE } 91-100 \\
\text { DEGREE } 101-05 \\
\text { DEGREE } 106-109 \\
\text { DEGREE } 110 \\
\end{array}$ & $\begin{array}{l}\text { Number of years between MA degree and Ph.D. } \\
\text { MA degree score from } 66 \text { to } 90 \\
\text { MA degree score from } 91 \text { to } 100 \\
\text { MA degree score from } 101 \text { to } 105 \\
\text { MA degree score from } 106 \text { to } 109 \\
\text { MA degree score from } 110\end{array}$ \\
\hline JOB FEATURES & $\begin{array}{l}\text { SELFEMPLOYED } \\
\text { PRODUCTS } \\
\text { PERMANENT } \\
\text { JOB SECTOR= } \\
\text { RDSERVICES } \\
\text { JOB SECTOR= ACADEMY } \\
\text { JOB SECTOR= } \\
\text { AGRICULTURE SECTOR= } \\
\text { JOB MANUFACTURE } \\
\text { MIGRANT PARTIME } \\
\text { TEACHING } \\
\text { PhDYRJOB } \\
\text { WKEXPYR RD=PARTIALLY RD } \\
\text { RD=NOT AT ALLS } \\
\text { RD=ONLY RD }\end{array}$ & $\begin{array}{l}1=\text { Self-employed } \\
\text { Number of products (publications, patent) realized } \\
\text { after Ph.D. completion } \\
1=\text { current job is permanent } \\
1=\text { Randd services is current job sector } \\
1=\text { current employer is an University } \\
1=\text { Agricolture is job sector: is current job sector } \\
1=\text { Manufacture is current job sector } \\
1=\text { moved to a different province from } \mathrm{Ph} . \mathrm{D} . \\
1=\text { part time job } \\
1=\text { teaches university courses } \\
1=\text { Did you work at } 1 \text { year after your PhD } \\
\text { Number of years of work experience after Ph.D.. } \\
1=\text { current job is partially focused on RandD } \\
1=\text { current job is does not include RandD at all. } \\
1=\text { current job is entirely focused on RandD }\end{array}$ \\
\hline $\begin{array}{l}\text { MACRO-REGION } \\
\text { OF RESIDENCE }\end{array}$ & $\begin{array}{l}\text { NORTHWEST } \\
\text { NORTEAST } \\
\text { CENTRE } \\
\text { SOUTH } \\
\text { ABROADS }\end{array}$ & $\begin{array}{l}1=\text { lives in the NW } \\
1=\text { lives in the } \mathrm{NE} \\
1=\text { lives in the Center } \\
1=\text { lives in the South } \\
1=\text { lives in abroad }\end{array}$ \\
\hline
\end{tabular}

Source: our elaboration on data from the ISTAT survey of doctoral recipients carried out in 2009. 